\title{
Geochemical and petrological studies of a magmatic carbonate-bearing metalamprophyre (spessartite) at Kalagalla - Evidence for shoshonitic calc-alkaline magmatism within auriferous Ramagiri-Penakacherla Schist Belt (2.5 Ga), Eastern Dharwar Craton, southern India
}

P. Ramesh Chandra Phani ${ }^{1^{*}}$ Raúl Lira ${ }^{2}$

María José Espeche ${ }^{2}$

R. Ananda Reddy ${ }^{3}$

${ }^{1}$ Cyient Limited

Hyderabad, India

${ }^{2}$ CONICET

National University of Córdoba

Córdoba Argentina

${ }^{3}$ Geological Survey of India Hyderabad India

Corresponding Author: phaniprc@gmail.com

\section{RESUMO}

Características geoquímicas e petrológicas de diques lamprófitos em Kalagalla intrudidas em rochas xistosas auríferas do cinturão de RamagiriPenakacherla, no distrito de Anantapur, Andhra Pradesh, Índia. O lamprófiro Kalagalla (KGL) é uma rocha melanocrática que exibe uma textura nodular típica na superfície. As micro-texturas e a mineralogia típica dos lamprófiros são obscurecidas pelo metamorfismo; no entanto, exibe textura porfirítica, nemato-granoblástica, representativa das fácies de xisto verde do metamorfismo. A rocha é cisalhada e possui vários glóbulos formados por agregados policristalinos de calcita (ocelli), envolvidas por plagioclásio coronítico sub-édrico e biotita, evidenciando sua origem manto-magmática. As assembleias minerais observadas em seções delgadas incluem anfibólio, plagioclásio, biotita, flogopita e calcita ocelli como essenciais, enquanto apatita, zircão, magnetita, ilmenita, calcopirita e pirita contendo Ni como fases acessórias. A investigação com SEM-EDS nos minerais acessórios revelou fases de sulfeto e silicato, como pirita livre de As, Ni-calcopirita hematitizada e minerais de Ni-As-Co indicativos de sulfetação associada aos veios auríferos de greenstones, além de silicatos como LREE-titanita parcialmente transformada em fases como leucoxeno e óxido como magnetita alterada para goethita em alguns locais. Com base na química mineral, geoquímica de rocha total, presença de anfibólio e dominância da plagioclásio, o KGL é classificada como uma variedade cálcio-alcalina em geral e como espessartita em particular, com afinidade shoshonítica. Nenhuma composição química anômala é observada na calcita ocelar. A titanita contendo LREE parece ser responsável pelo enriquecimento de LREE. O alto Mg \# (77-79), Ni (153-162 ppm) e Cr (380-470 ppm) dão suporte a uma fonte mantélica. A ausência de anomalia de Eu reflete a falta de fracionamento do plagioclásio. A alta relação $\mathrm{Zr} / \mathrm{Hf}$ (163-202) indica ausência de contaminação crustal e contribuição de carbonato magmático na fonte para formar ocelos como produto da imiscibilidade tardia de líquido silicato-carbonato líquido no mecanismo de segregação. Os padrões de traços e de REE ( $\mathrm{REE}$ : 326-343 ppm, LREE> HREE) indicam envolvimento de granada residual na fonte presumivelmente enriquecida em flogopita em um ambiente "relacionado à subducção".

Palavras-chave: Lamprófiros, alcalino-calcário, espessartito, shoshonítico, carbonato magmático ocelli, subducção, cinturão de xisto RamagiriPenakacherla 


\section{ABSTRACT}

Geochemical and petrological characteristics of lamprophyre dykes at Kalagalla intruded into the auriferous schistose rocks of the RamagiriPenakacherla Schist Belt, Anantapur district, Andhra Pradesh, India are presented here. The Kalagalla lamprophyre (KGL) is a melanocratic rock exhibiting typical knobby or pustular texture on the surface. The microtextures and mineralogy typical of lamprophyres are obscured by metamorphism; however, it exhibits porphyritic, nemato-granoblastic texture representative of greenschist facies of metamorphism. The rock is sheared and possesses several globules formed by polycrystalline aggregates of calcite rimmed by coronitic subhedral plagioclase and biotite, evidencing its mantle-magmatic origin. The mineral assemblages noticed in thin-sections include amphibole, plagioclase, biotite, phlogopite and calcite ocelli as essential while apatite, zircon, magnetite, ilmenite, Ni-bearing chalcopyrite and pyrite as accessory phases. The SEM-EDS investigation on the accessory minerals revealed accessory sulphide and silicate phases like As-free pyrite, haematitised Ni-bearing chalcopyrite and Ni-As-Co- minerals indicative of sulphidation associated with greenstone auriferous lodes, along with silicates like LREE-bearing titanite partially transformed into leucoxene and oxide phases like magnetite altered to goethite at places. Based on mineral chemistry, whole rock geochemistry, presence of amphibole and dominance of plagioclase, the KGL is classified as a calc-alkaline variety in general and as spessartite in particular possessing shoshonitic affinity. No anomalous chemical composition is noticed in the ocellar calcite. The LREE-bearing titanite appears to be the contributor of LREE enrichment. The high Mg\# (7779), Ni (153-162 ppm) and $\mathrm{Cr}(380-470 \mathrm{ppm})$ support a mantle source. The absence of Eu anomaly reflects lack of plagioclase fractionation. The high $\mathrm{Zr} / \mathrm{Hf}$ ratio (163-202) indicates absence of crustal contamination and contribution of magmatic carbonate at the source to form ocelli as product of late-stage liquid silicate-carbonate immiscibility of segregation mechanism. The trace and REE patterns ( 2 REE: $326-343$ ppm, LREE $>$ HREE) indicate involvement of residual garnet at the source presumably enriched in phlogopite in a 'subduction-related' environment.

Keywords: Lamprophyre, calc-alkaline, spessartite, shoshonitic, magmatic carbonate ocelli, subduction, Ramagiri-Penakacherla Schist Belt.

\section{INTRODUCTION}

In recent times, the study of lamprophyres has attracted the attention of petrologists as a tool to unlock the information pertaining to the crustal evolution, tectonics and magmatism; in India these rocks have helped in understanding the geotectonic and magmatic evolution of the Eastern Dharwar Craton (EDC). Lamprophyres are a part of mantle-derived potassic to ultrapotassic magmatism, a typical feature of collisional orogens and oceanic subduction zones. Lamprophyres carry vast information concerning chemical and mineralogical conditions of the uppermost mantle. Lamprophyres are porphyritic rocks comprising phenocrysts of mafic minerals and apatite embedded in a groundmass that has the same composition of early crystallised mineral phases (e.g. phlogopite, olivine, amphibole, clinopyroxene and apatite) along with alkali feldspar and/or plagioclase. As recommended by the International Union of Geological
Sciences (IUGS), the lamprophyres are classified into three categories: (i) alkaline (e.g. STOPPA et al. 2014), (ii) calc-alkaline (e.g. GARZA et al. 2013), and (iii) ultramafic (e.g. NASIR 2016). Genetically, lamprophyre rocks are referred to as ultramafic, mafic and/or intermediate rocks that intrude the basement at shallow crustal levels and occur in the form of plugs, dykes or sills (ROCK 1991). In southern India, occurrences of a variety of mantle-derived rocks like lamprophyres, lamproites, kimberlites and their entrained xenolith cargo have been utilized as clues to interpret the nature and evolution of the subcontinental lithospheric mantle (SCLM) beneath the EDC (e.g. CHALAPATHI RAO 2004, 2007, 2013; CHAKRABARTI et al. 2007; DONGRE et al. 2015; PANDEY et al. 2017; PANDEY et al. 2017, 2018).

All the three categories of lamprophyres are reported from different domains of the Indian 
shield. Lamprophyres occur in different kinds of lithological, tectonic, geochronological and cratonic domains in India (Fareeduddin and Mitchell 2012) and greenstone belts are not an exception. Pandey et al. (2018) have reported mineralogical, geochemical and isotopic characteristics of three lamprophyre dykes occurring in Kadiri Schist Belt (KSB). The KSB contains $\mathrm{Au}$ values ranging from 25 to $2800 \mathrm{ppb}$ in a rhyodacite unit at very few places (RAMAMURTHY; ANANDAMURTHY 1994). However, economic quantities of gold in the KSB are apprehensive due to the presence of different lithological conditions such as dominance of felsic volcanics (DEY et al. 2013, 2014), absence of schistose rocks (chlorite schist, mafic volcanics), structural loci, and the appropriate type of hydrothermal quartz veins as in the case of other economically mineralised schist belts of the Dharwar Craton. Lamprophyres were also reported from other auriferous schist belts of India such as Nuggihalli Schist Belt (NSB) (SUGAVANAM et al. 1994). Furthermore, several lamprophyres in supracrustal belts have been brought into light through petrological investigations. These include lamprophyres at Jungel (SRIVASTAVA ; CHALAPATHI RAO 2007) and Chitrangi (SRIVASTAVA 2013) within the Mahakoshal Supracrustal Belt (MSB), central India. More than a hundred lamprophyre occurrences have been reported in the Prakasam Alkaline Province (PAP) and also along the margins of the Cuddapah basin (LEELANANDAM; RATNAKAR 1980; SUBRAHMANYAM et al. 1987; RATNAKAR et al. 1995, 1996; MADHAVAN et al. 1992, 1998; RATHNA et al. 2000; VIJAYA KUMAR; RATHNA, 2008; MESHRAM; VENKATESWARA RAO, 2009; MESHRAM et al. 2015; ADHIKARY 2017). However, two of the six dyke occurrences reported as lamprophyres at Kalwakurty

(MESHRAM;
VENKATESWARA RAO 2009) were recently reclassified as pyroxenites (GIRI et al. 2019). In the Wajrakarur Kimberlite Field (WKF) and its environs in Anantapur district, Andhra Pradesh, several lamprophyres were located by the Geological Survey of India (GSI) at Udiripikonda, Sivarampet, Nagireddypalli, Kalagalla and Korrakodu (SHIVANNA et al. 2002). All these occurrences together with other related rock types, in and around the Cuddapah basin, constitute a regional tectonic environment which is described as Cuddapah Intrusive Province (CIP; MADHAVAN et al. 1998; Fig.1). In addition to these, several other solitary intrusive occurrences suspected to be lamprophyres exist within the WKF at Antarganga $\left(14^{\circ} 45^{\prime} 50.18^{\prime \prime N} \quad 77^{\circ} 25^{\prime} 29.44^{\prime \prime} \mathrm{E}\right)$, Kammuru (144 $\left.44^{\prime} 44.11^{\prime \prime} \mathrm{N} \quad 77^{\circ} 29^{\prime} 1.48^{\prime \prime} \mathrm{E}\right)$, Nimbagallu $\quad\left(14^{\circ} 53^{\prime} 25.98^{\prime \prime} \mathrm{N} \quad 77^{\circ} 12^{\prime} 32.68^{\prime \prime} \mathrm{E}\right)$ and Vaddipalli $\quad\left(14^{\circ} 40^{\prime} 19.57^{\prime \prime} \mathrm{N}\right.$ $77^{\circ} 27^{\prime} 26.59^{\prime \prime E}$ ), which need additional field work and eventually warrant detailed investigations (KAMESWARA RAO; RAGHU PRASADA RAO, GSI, Hyderabad. pers. comm., 2009). Although the geochemical and petrological aspects of some of these lamprophyres namely Udiripikonda (PANDEY et al. 2016, 2017), Mudigubba (PANDEY et al. 2017), Sivarampet (PHANI et al. 2018, KHAN et al. 2018, PANKAJ et al., 2020), Kadiri (PANDEY et al. 2018), Korrakodu (RAGHUVAMSHI et al. 2019) are published to date, the geochemical and petrological behaviour of lamprophyre occurrence at Kalagalla is yet to be reported. Therefore, in this paper an attempt is made to present primary information pertaining to field aspects, mineralogical, geochemical and petrological characteristics of lamprophyre dykes occurring at Kalagalla (KGL- Kalagalla lamprophyre), within the gold-bearing RamagiriPenakacherla Schist Belt (RPSB), west of Cuddapah basin in Anantapur district, Andhra Pradesh.

\subsection{LAMPROPHYRES ASSOCIATED WITH AURIFEROUS/ORE-BEARING GREENSTONE BELTS}

Several lamprophyres have been reported worldwide as occurring in association with gold-bearing greenstone belts (ASHLEY et al. 1994; MÜLLER; GROVES 2019). Such lamprophyres have an intimate association with the auriferous lodes and are regarded as indicators of greenstone hosted gold mineralisation. Many workers have elucidated that an extremely close genetic relation exists between calc-alkaline (shoshonitic) lamprophyres and mesothermal gold deposits of several greenstone belts across the globe (ROCK et al. 1989; TAYLOR et al. 1994; ASHLEY et al. 1998). Archaean greenstone belts comprise a variety of bimodal metavolcanics with variable types of clastic 
sediments and volcanic to sub-volcanic rocks such as tholeiitic basalt, komatiite, arc-related basalt, boninite, adakite, siliceous high $\mathrm{Mg}$ basalt and lamprophyre. These rocks are significant in providing clues on geodynamic mechanisms of earth's evolutionary history (CURRIE; WILLIAMS 1993; CONDIE, 1994; NAQVI et al. 2006; POLAT; KERRICH, 2001; SRIVASTAVA, 2008, 2013; SRIVASTAVA et al. 2004; ANHAEUSSER, 2014).

It is well-known that, in addition to their association with gold mineralization, Precambrian lamprophyres act as geological marker horizons in gold exploration (WYMAN; KERRICH 1988, PERRING et al. 1989, KWELWA 2017; KERRICH, 1986; ROCK; GROVES 1988; KERRICH; WYMAN 1994; DUBE et al. 2004). In the Superior Province of Canada, the gold mineralisation was originated in deep sources and emplaced along a major deep-seated structure that hosts volatile-rich lamprophyres. Here the gold mineralisation is related to a common tectonic regime, however from different source regions (WYMAN; KERRICH 1988, SIMS; DAY 1992). A review of lamprophyres associated with auriferous schist belts is presented in Table 1. In this context, the lamprophyre under present study attains significance to understand the geological evolution of the area under study.

Owing to the close spatial association between lamprophyre dykes and gold mineralization, devolatilisation of shoshonitic lamprophyre magma during crystallization has been postulated as a possible source of gold in orogenic lode deposits (ROCK; GROVES 1988; ROCK et al. 1988, 1989). This type of association is observed in Archaean greenstone terranes (KERRICH; WYMAN 1994) and in famous gold mines such as 'Golden Mile' (MUELLER et al. 1988; MCNAUGHTON et al. 2005) and 'New Celebration' (WILLIAMS 1994).

Lamprophyres are neither intrinsically rich in gold mineralisation nor they are volumetrically significant in orogenic gold deposits. However, their temporal and spatial relationship is considered to reflect formation in a common geodynamic setting (KERRICH; WYMAN 1994) in orogenic lode gold deposits, rather than a viable source for gold mineralisation as in the case of Darlot deposit (KENWORTHY; HAGEMANN 2005). Furthermore, association of lamprophyres and rare metal- rare earth elements (RM-REE), $\mathrm{Pb}$ $\mathrm{Zn}, \quad \mathrm{Sb}-\mathrm{Hg}, \quad \mathrm{Sn}-\mathrm{W}, \quad \mathrm{Sn}$-sulphide, $\mathrm{Ag}-\mathrm{Sb}$ mineralisation has been emphasized by several workers (ŠTEMPROCK; SEIFERT 2011 and references therein). It should be noted that the shoshonitic lamprophyres are reported to contain diamonds also as seen in the case of Wawa region, Canada (LEFEBVRE et al. 2005). Hence, shoshonitic lamprophyres are significant not only for understanding the tectonics and magmatic evolution of the continental masses but also significant from the economic perspective (e.g. SCARROW et al. 2011).

\section{GEOLOGICAL SETTING AND FIELD RELATIONS}

The Dharwar craton is composed of granites, gneisses of Archaean age with numerous greenstones, mafic and felsic intrusions of Proterozoic age. The craton also includes sedimentary depositional domains such as Cuddapah, Kurnool, Bhīma and Kaladgi basins comprising a variety of clastic and non-clastic rocks of Proterozoic age (RAMAKRISHNAN; VAIDYANATHAN 2008). The Archaean granitic rocks belong to the trondhjemite- tonalite- granodiorite (TTG) suites which are collectively termed as the Peninsular Gneissic Complex (PGC). The Dharwar craton is divided into two prominent domains namely the Eastern Dharwar Craton (EDC) and the Western Dharwar Craton (WDC) distinctly separated by the Chitradurga
Shear Zone associated with mylonite, located at the eastern extremity of Chitradurga Schist Belt, which includes the linearly, nearly NStrending Closepet granite intrusion (SWAMINATH et al. 1976; FRIEND; NUTMAN 1991). The WDC is made up of gneisses and greenstones of 3.0 to $3.3 \mathrm{Ga}$ age, with very few $2.5 \mathrm{Ga}$ granites, while the EDC is made up of younger $(2.7$ to $3.0 \mathrm{Ga})$ lithological units with widespread elongated plutons of Late Archaean granitoids (MOYEN et al. 2003; Fig. 1a). The EDC comprises several linear schist belts named after the nearest major location such as RamagiriPenakacherla, Kadiri, Jonangiri, Julakalva, Gadwal and Peddavura. 


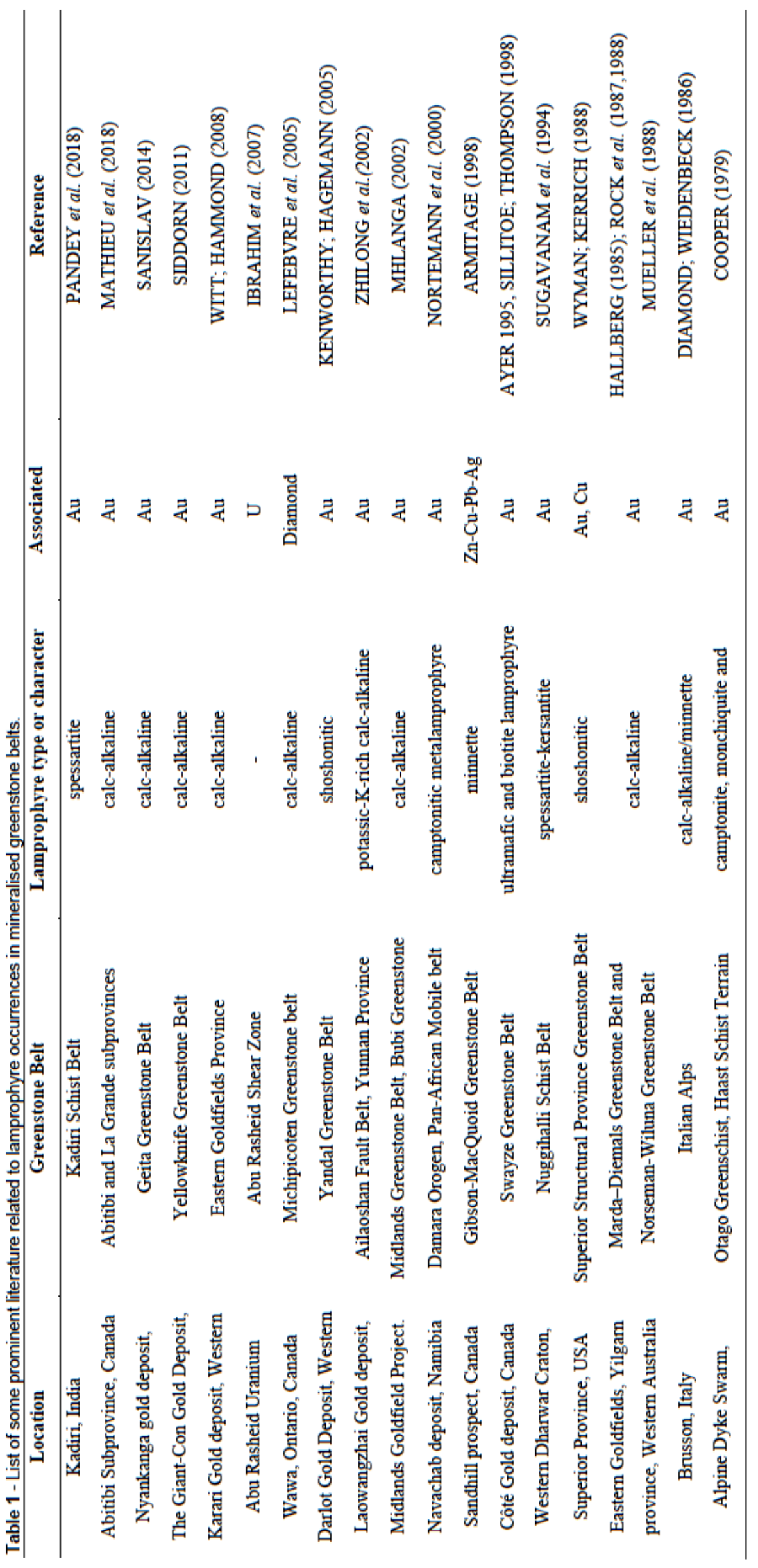


The RPSB is a part of Ramagiri-Hungund Schist Belt extending for about $180 \mathrm{~km}$ dominantly composed of pillowed basaltic rocks, felsic volcanics, volcanoclastites, metandesites and gabbros, banded iron formations, conglomerates, hornfelsed greywackes and phyllites with intrusions of ultramafics and syn to late-tectonic younger potassic granites and granodiorites (RAMAKRISHNAN; VAIDYANATHAN 2008). All these litho-units are tightly folded and have experienced upper greenschist to lower amphibolite facies of metamorphism, with basalts retaining pillow structures (MANIKYAMBA et al. 2004). The lithologic units display a N-S to NNW-SSE trend, with a width ranging from 1.5 to $8 \mathrm{~km}$. Mylonite zones occur as margins on either sides of this linear schist belt. The favourable host for gold mineralisation in Ramagiri Gold Field is the schistose pillowed metabasalt (VASUDEV 2009). The litho-units in the northern part of the RPSB at Penakacherla are well exposed. The metamorphism and deformation under NE-SW compression associated with the Archaean subduction process transformed metavolcanics into amphibolites and intermediate to felsic volcanics into quartz micaschists. The prolonged compression has generated a 50-150 km wide shear zone consisting of mafic phyllonites. The goldbearing sulphides occur in sheared grey to smoky quartz veins, in association with carbonates, emplaced within quartz-chloritesericite or quartz-sericite schist. These are sheared and altered products of parent andesitic lava at a late stage of folding where silica was released. The localisation of gold occurs in the first generation of narrow ductile shear zones where sericitisation is a common feature of alteration. The early-formed quartz veins, which underwent shearing are favourable for gold mineralization, with higher concentration in synclinal troughs (VASUDEV 2009). The metabasalts from RPSB have been dated at $2746 \pm 64 \mathrm{Ma}$ by $\mathrm{Pb}-\mathrm{Pb}$ methods (ZACHARAIAH et al. 1996), which is consistent with SHRIMP U-Pb zircon ages of

\section{SAMPLING, ANALYSES AND DATA USED}

Detailed field traverses were conducted during the years 2016-2017 to locate the KGL based on GSI maps. The lamprophyre samples were collected from the dumps piled up from metarhyolites $(2658 \pm 14 \mathrm{Ma}$; NUTMAN et al. 1996).

The study area forms a part of the WKF, wherein more than 45 kimberlites and olivine lamproites (SHAIKH et al., 2016) and more than six lamprophyres emplaced into the granitoid gneissic country-rock are known. The WKF emplaced with a variety of Kimberlite Clan Rocks (KCR) offers a unique geological set up to understand the deepmantle mechanisms and large-scale geodynamic processes. In recent times, several intrusions which were hitherto believed to be Group-I kimberlites are reclassified as olivine lamproites (CHALAPATHI RAO et al., 2019). Geomorphologically, the study area is a rugged pediplain-pediment-inselberg complex traversed by linear ridges. The KGL location is situated at about $3 \mathrm{~km}$ ENE of Kalagalla

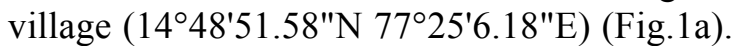
The lamprophyre dykes are exposed in the shaft wall of an ancient gold mine in the form of two to three bands with an average width ranging from 10 to $20 \mathrm{~cm}$, intruding into the chlorite schists of RPSB (Fig.1b). However, the thick colluvial cover obscures the true trace and dimension of the dykes. The intrusion is sheared and shows banded structure. The rock is free from crustal xenoliths and exhibits pitted surfaces showing knobby or pustular texture due to removal of vulnerable minerals by weathering (Fig.1c and d). The rock contains identifiable carbonate ocelli (1-2 mm) and sporadic disseminations of sulphides (pyrite). The host rock of the KGL, chlorite schist is a dominant rock type in the central part of the RPSB possessing a NNW-SSE strike with a dip of $65^{\circ}$ to $70^{\circ}$ due SW. It is flanked by schistose metabasalts on either side. The chlorite schist is also traversed by a number of grey quartz veins hosting the main gold-bearing sulphide mineralization, trending in $\mathrm{N} 55^{\circ} \mathrm{W}-\mathrm{S} 55^{\circ} \mathrm{E}$ to $\mathrm{N} 65^{\circ} \mathrm{W}-\mathrm{S} 65^{\circ} \mathrm{E}$ direction. Specks of metallic sulphide (pyrite) crystals are also observed within the host-rock metabasalts of RPSB. Ferruginous quartzites are also found to be associated with chlorite schists as discontinuous bands of 15 to 20 meter width for a length of 5 to 12 meters. 
sections were made at Gita Laboratories, Kolkata and studied under a polarizing microscope (Leica DM750P) at the Department of Geology, University College of Science (Saifabad), Osmania University, Hyderabad. The major, trace and rare earth element concentrations were determined using standard digestion techniques at Shiva Analyticals (India) Pvt. Limited, Bangalore, deploying XRF and ICP-MS and ICP-OES. Analyses of certified standards and repetitive analyses were also conducted to demonstrate the accuracy and precision of determination for major, trace and REE concentrations. All the samples were crushed and pulverized carefully in tungsten carbide mortar adopting standard equipment and procedures. The various geochemical indices were calculated using a software programme developed by Prof. Kurt Hollocher, Geology Department, Union College, Schenectady, New York, USA.
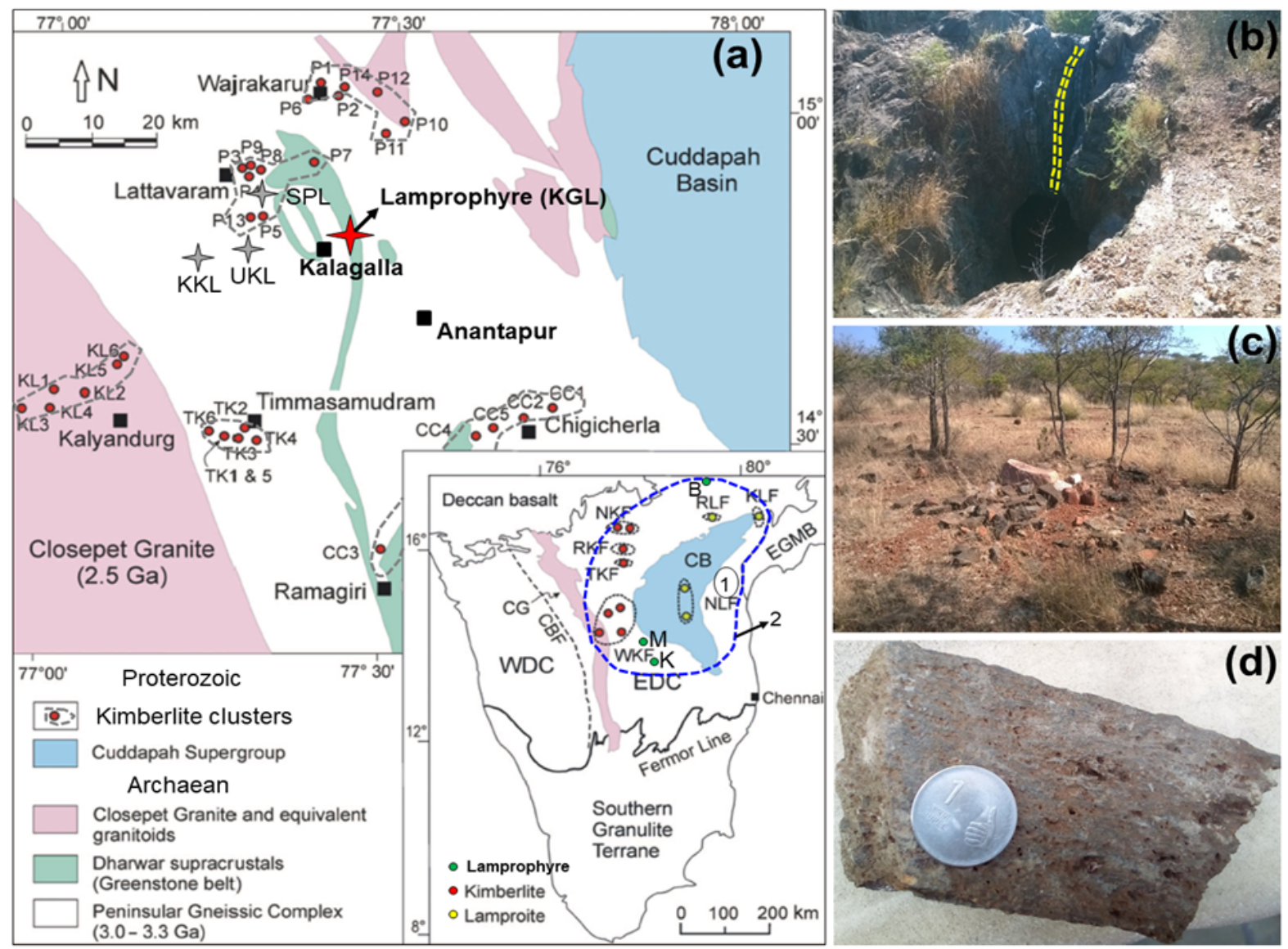

Figure 1

a) General geological map showing location of Kalagalla lamprophyre (KGL) within the Wajrakarur kimberlite field, showing lamprophyre and kimberlite occurrences (modified after Nayak and Kudari 1999). Grey stars indicate lamprophyres of Korrakodu (KKL), Sivarampet (SPL) and Udiripikonda (UKL). The KGL is shown as a red star. Inset: Regional geological map of the Dharwar Craton with kimberlite fields (modified after Ravi et al. 2009). Abbreviations: 1. Location of Prakasam Alkaline Province, 2. hypothetical boundary of Cuddapah Intrusive Province. B-Bayyaram lamprophyre, CB-Cuddapah basin, CBFChitradurga Boundary Fault, CG-Closepet granite, EDC-Eastern Dharwar Craton, EGMB-Eastern Ghats Mobile Belt, K-Kadiri lamprophyre, M-Mudigubba lamprophyre, WDC-Western Dharwar Craton. Kimberlite/Lamproite Fields (KF/LF): NKFNarayanpet, RKF-Raichur, TKF-Timmasamudram, WKF-Wajrakarur, and KLF-Krishna, RLF- Ramadugu, NLF-Nallamala. (b) An old gold pit within the Ramagiri Penakacherla Schist Belt where the KGL (yellow dashed lines in the shaft roof) is located. Camera facing northeast. (c) Lamprophyre boulders piled up from the excavation (d) Hand specimen of lamprophyre showing pustular texture. Coin diameter $=2.5 \mathrm{~cm}$.

In order to identify general composition and possible trace element anomalies in accessory mineral phases such as sulphides and silicates, scanning electron microscopy (SEM) images and energy dispersive spectroscopy (EDS) analyses were carried out using Oxford
Scanning Electron Microscope located at the Laboratory of Electron Microscopy and X-ray Analysis (LAMARX), Faculty of Mathematics, Astronomy, Physics and Computing of the National University of Córdoba, Argentina. For obtaining the semi- 
quantitative data, the machine was operated at an accelerating voltage of $15 \mathrm{kV}$ and a working distance of $8.5 \mathrm{~mm}$ and aperture size 60 micrometers. The mineral chemistry of essential and accessory mineral phases has also been studied using electron probe microanalyser (EPMA, JEOL JXA 8230) with an accelerating voltage of $15 \mathrm{kV}$, a beam current of $10 \mathrm{nA}$ and a beam diameter of $1 \mu \mathrm{m}$ at the LAMARX, Argentina. A number of standards such as diopside $(\mathrm{Ca})$, peridot $(\mathrm{Mg})$, $\mathrm{FeS}_{2}(\mathrm{Fe})$, orthoclase $(\mathrm{K})$, rutile $(\mathrm{Ti}), \mathrm{NaCl}$ $(\mathrm{Na})$, apatite $(\mathrm{P}), \mathrm{CaSiO}_{3}(\mathrm{Si})$ and kyanite $(\mathrm{Al})$ were used for standardization. To ascertain the accuracy in determining the mineral chemistry, several repeat analyses were carried out. The counting time was 10 s with an error $<1 \%$.

\section{PETROGRAPHY AND MINERALOGY}

Although the rock has a primary aphanitic texture that has undergone metamorphism, still faint textural signatures of lamprophyre such as porphyritic, globular or ocellar texture in ovoidal to amoeboidal shape are observed. Its aphanitic nature makes the identification of mineral assemblage challenging to classify this lamprophyre to a definite class. Euhedral magnetite and ilmenite crystals are observed within an indiscernible groundmass made up of biotite-phlogopite, amphiboles and chlorite. The groundmass shows grano-nematoblastic texture indicating the effect of metamorphism (Fig.2a). Circular arrangements of magnetite and amphiboles grains giving rise to ocellar texture are another diagnostic feature. The groundmass is at places chloritised, indicating low grade metamorphism. (Fig.2b). Plagioclase and biotite occur in mutual relation with carbonate ocelli reflecting their primary nature. Presence of some Fe- oxide/hydroxide presumed to be goethite appearing in blood red tinge and incipient colour zoning is noticed. The carbonate ocelli sometimes show

\subsection{EMPA RESULTS}

Some representative EPMA analyses were conducted on essential mineral phases and the
The geochemical data of lamprophyres from various localities of the EDC and CIP such as Kellampalli (RATNAKAR et al. 1996), Purimetla (MADHAVAN et al. 1998) Bayyaram (MESHRAM et al. 2015), Sivarampet (PHANI et al. 2018), and Kadiri (PANDEY et al. 2018), has been used for comparison purpose. The Sivarampet and Kadiri lamprophyres are in Anantapur district, $15 \mathrm{~km}$ northwest and $118 \mathrm{~km}$ southeast of KGL respectively. The Purimetla and Kellampalli lamprophyres are situated on the eastern side of the Cuddapah basin, about 300 $\mathrm{km}$ north east of the KGL. The Bayyaram lamprophyre is situated about $420 \mathrm{~km}$ north east in the north western margin of Cuddapah basin.

glomeroporphyritic texture (Fig.2c). Occasionally euhedral grains of zircon are observed, within the metamorphosed groundmass. At places, hornblende is partially replaced by actinolite. Chlorite appears to be formed from alteration of amphibole. (Fig.2d). The SEM-EDS study also revealed that the carbonate ocelli are surrounded by plagioclase and biotite crystals in coronitic texture, supporting their magmatic nature. The plagioclase crystals show simple twin lamellae. The calcite grains in the ocelli show multiple sets of twinning and twinkling (Fig.2e). Euhedral xenocrystals of pyrite and titanite were observed (Fig. 2f and g). Pyrite crystals exhibit haematitisation in the borders (Fig. 2h). In overall observation, the KGL samples show porphyritic, grano-nematoblastic and glomeroporphyritic textures, and clearly appear to have undergone alteration as a consequence of low grade metamorphism. The overall mineral assemblage and abundance of plagioclase classifies the KGL as spessartite.

results are detailed below.

\subsubsection{FELDSPARS}

Feldspars occurring in the fine-grained groundmass $(n=6)$ and those occurring at the peripheries of calcite ocelli $(n=7)$ have been analysed. Results are shown in Table 2. The average composition of groundmass feldspars is $\mathrm{Or}_{1.84} \mathrm{Ab}_{86.26} \mathrm{An}_{11.90}$ while that of feldspars associated with calcite ocelli in the KGL is $\mathrm{Or}_{0.86} \mathrm{Ab}_{82.01} \mathrm{An}_{17.13}$, both ranging from albite to 
oligoclase (Fig. 3). In general, the albitisation of calcic plagioclase reflects involvement of hydrothermal alteration which is a common characteristic of the lamprophyre clan of rocks (e.g. PANDEY et al. 2017). Though it was difficult to notice any albitisation in the microphenocrystic feldspars during petrographic study, the mineral chemistry indicates predominance of albite in composition. The mineral chemistry of feldspars of calcite ocelli and the groundmass are similar suggesting magmatic origin, though plagioclase from ocelli textures is richer in molar anorthite ( $>5 \%$ in average molar An). The feldspars of Korrakodu lamprophyres show a range of composition from albite to orthoclase while those of Kadiri and Mudigubba show distinct dominance of plagioclase ranging from albite to labradorite (RAGHUVAMSHI et al. 2019). The predominance of plagioclase feldspars and absence of orthoclase (LE MAITRE 2002) classifies the KGL as spessartite type.

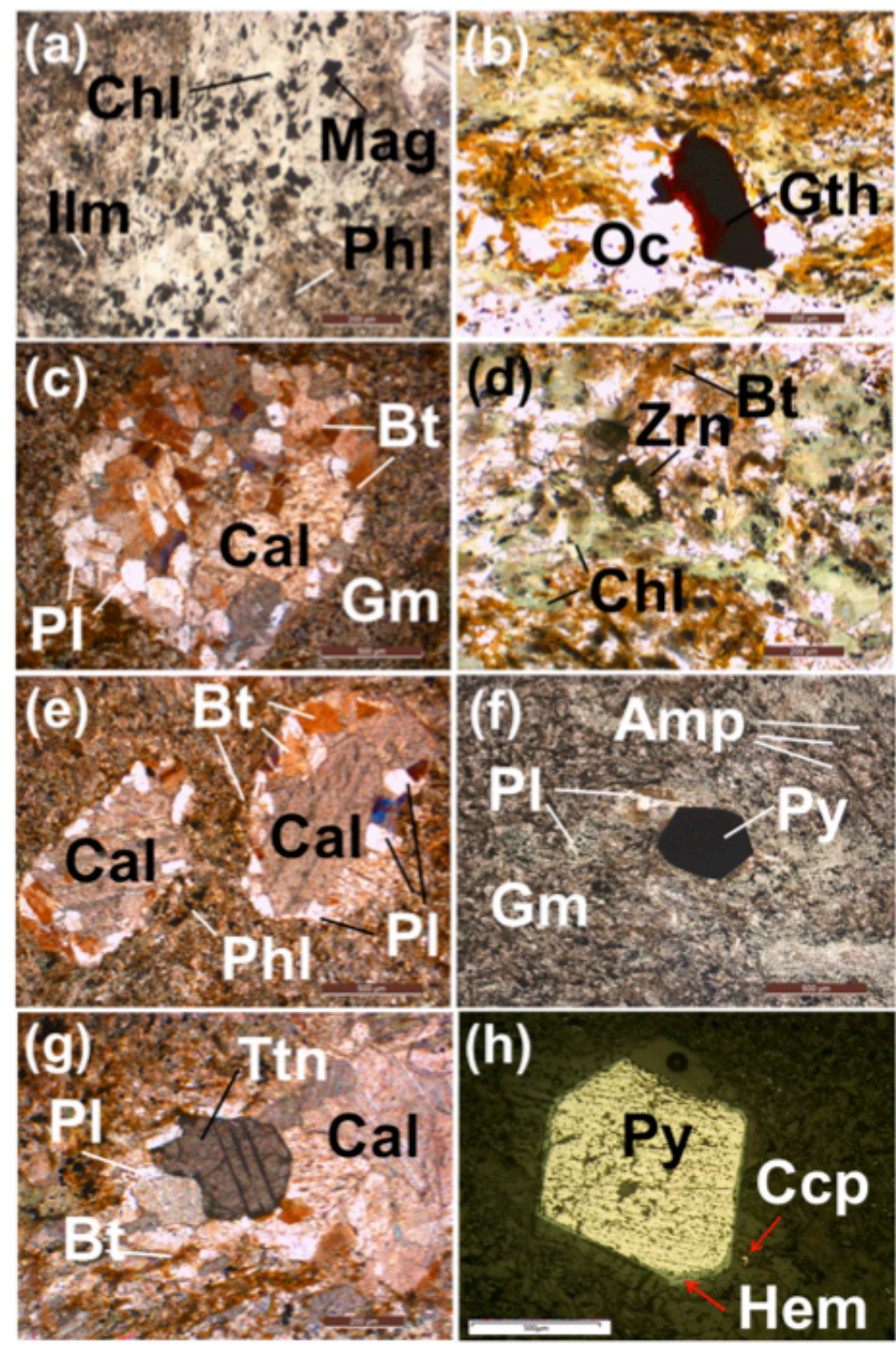

Figure 2.

Microphotographs showing textural and mineralogical features of Kalagalla lamprophyre. (a) Well developed euhedral magnetite and ilmenite crystals in metamorphosed matrix (PPL). (b) Globular arrangement of amphiboles and irregularly grown reddish brown goethite within the nemato-granoblastic fabric of lamprophyre (XPL). (c) Carbonate ocellum as a glomeroporphyritic aggregate. (d) Zircon crystal within the metamorphosed matrix. Chlorite derived after amphibole (PPL). (e) Calcite ocelli with minor amounts of biotite, plagioclase crystals and suspected phlogopite in the peripheries (XPL). (f) Euhedral pyrite crystal within the metamorphosed groundmass exhibiting nemato-granoblastic texture. Note tiny prisms of amphiboles and plagioclase associated with groundmass. (g) Euhedral titanite crystal associated with calcite ocelli within the lamprophyre groundmass (XPL). (h) SEM photograph of pyrite crystal with haematite border and a small grain of chalcopyrite. Abbreviations: Ampamphibole, Bt-biotite, Cal-calcite/carbonate, Chl-chlorite, Ccp-chalcopyirte, Gth-goethite, Gm-groundmass, Hem-haematite, Ilmilmenite, Mag- magnetite, Phl-phlogopite, Pl-plagioclase, Py- As-free pyrite, Oc-ocellum, Ttn-Al-rich titanite, Zrn-zircon, PPLunder plane polarised light and XPL- under crossed Nicols. 


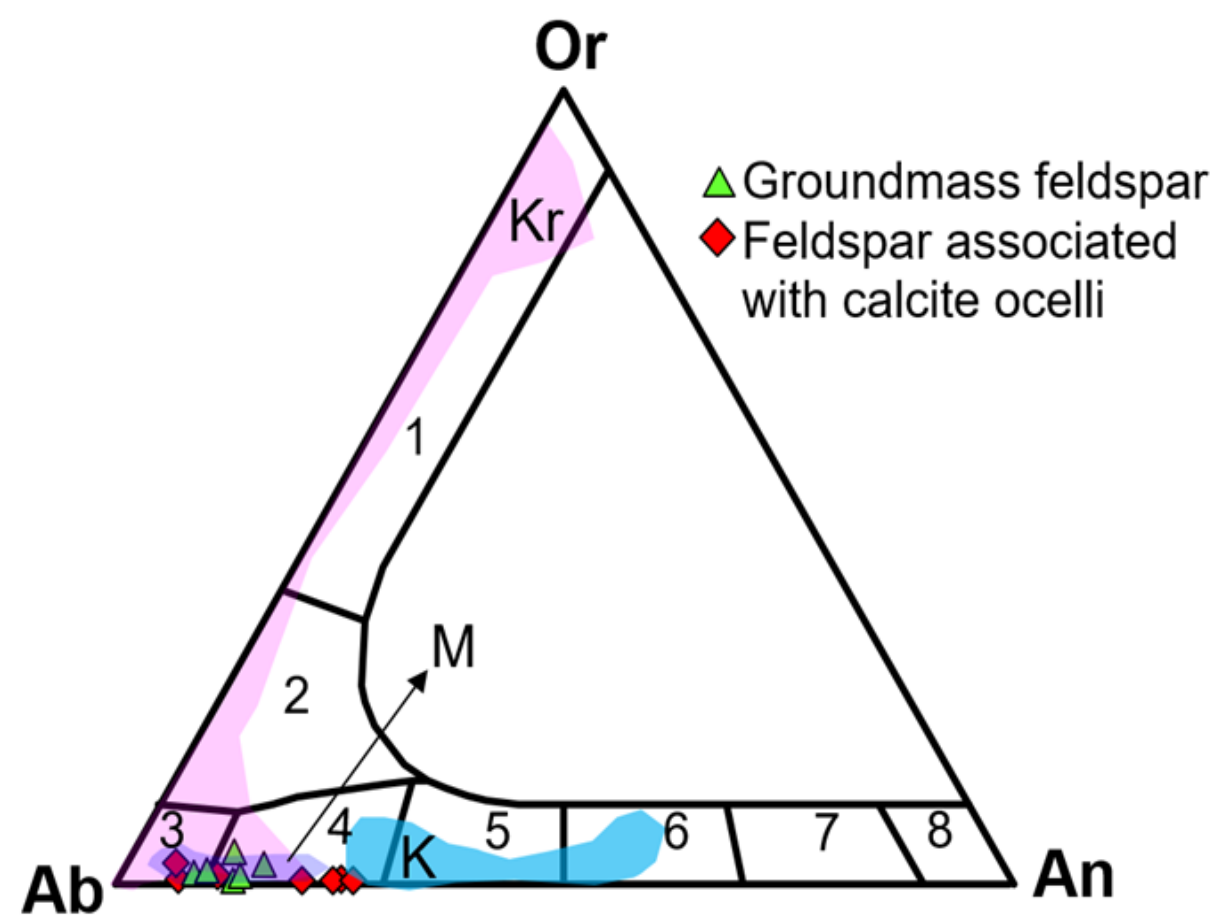

Figure 3

Classification of feldspars in the KGL. 1. sanidine, 2. anorthoclase, 3. albite, 4. oligoclase, 5. andesine, 6. labradorite, 7. bytownite, 8. anorthite. Fields for Kadiri (K), Korrakodu (Kr), Mudigubba (M) lamprophyres are from Raghuvamshi et al. (2019).

\subsubsection{AMPHIBOLES}

The amphiboles $(\mathrm{n}=8)$ of the KGL are classified as magnesio-hornblende and actinolite (Fig.4a) as per IMA classification (LEAKE et al. 1997). Even though the rock has undergone metamorphism, the primitive igneous character of amphibole is preserved in the KGL. Mineral chemistry of amphiboles of the KGL are shown in Table 3. Amphiboles

\subsubsection{MICAS}

Only biotite phenocrysts developed at the borders of calcite ocelli have been analyzed by EPMA. Results are shown in Table 4. The $\mathrm{Mg \#} \mathrm{(0.41-0.46)}$ of the KGL classifies the micas as biotite. The biotites show a very high $\mathrm{Al}_{2} \mathrm{O}_{3}$ content (15- 18 wt. \%) clearly imparting calc-alkaline and shoshonitic character to the show depletion in $\mathrm{TiO}_{2}(<0.3 \mathrm{wt} \%)$ which is in line with the calc-alkaline nature of the lamprophyre melt (Fig.4b). The presence of actinolite in the KGL is supportive to the low grade metamorphism that the lamprophyre has undergone. The composition of amphiboles of the KGL is similar to Kadiri and Mudigubba lamprophyres.

\subsection{SEM-EDS ANALYSES OF ACCESSORY MINERAL PHASES}

The SEM-EDS study revealed that the proportion of oxides (e.g. magnetite and ilmenite) is more than sulphides (e.g. pyrite
KGL (JIANG et al. 2010). Petrographic examination reveals that the chlorite is an alteration product of amphibole formed during metamorphism. The micas of KGL show similar geochemical behaviour to lamprophyres of Kadiri, Korrakodu, Udiripikonda and the CIP (Fig.5a and b).

$$
\text { assemblages. }
$$




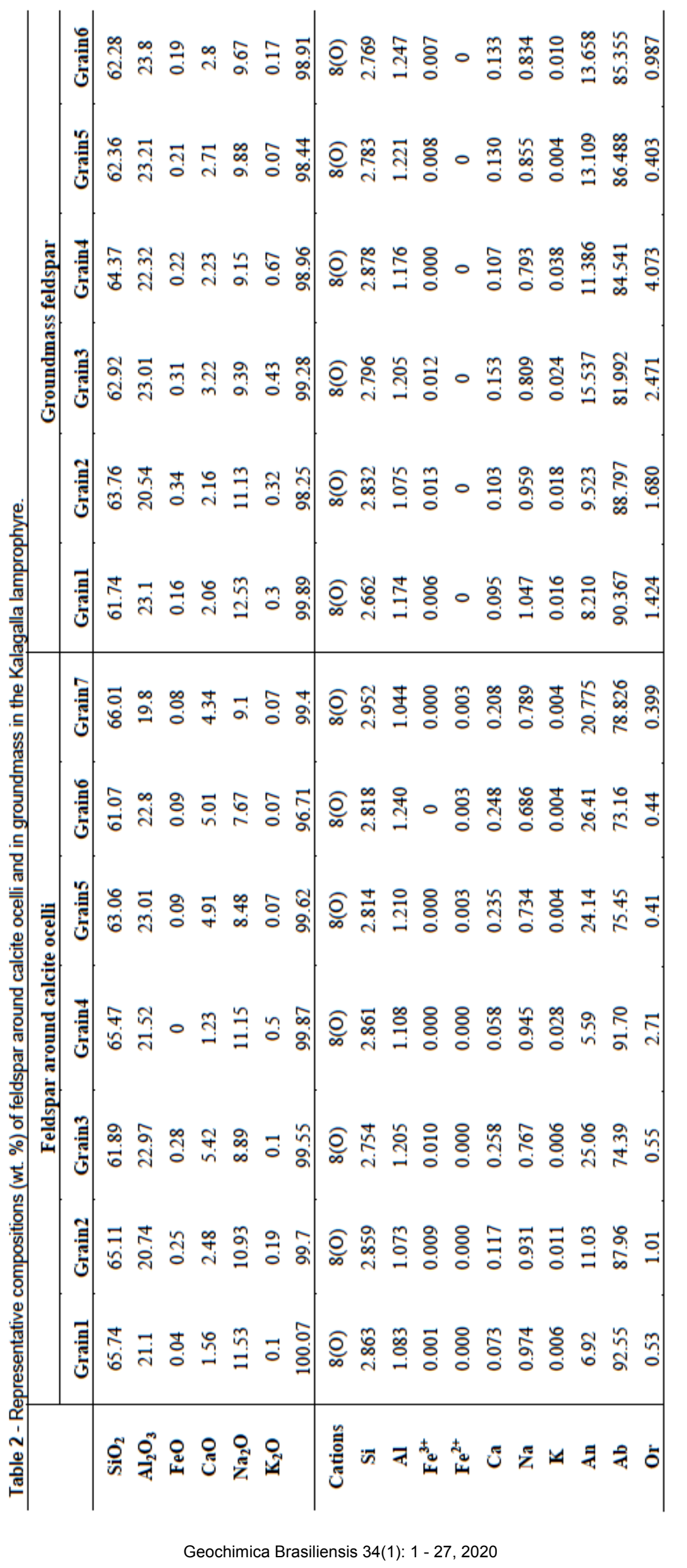


Table 3. Representative chemical compositions of amphiboles of the KGL.

\begin{tabular}{|c|c|c|c|c|c|c|c|c|}
\hline & Grain1 & Grain2 & Grain3 & Grain4 & Grain5 & Grain6 & Grain 7 & Grain8 \\
\hline $\mathrm{SiO}_{2}$ & 50.18 & 55.92 & 55.33 & 45.42 & 48.03 & 49.2 & 50 & 49 \\
\hline $\mathrm{TiO}_{2}$ & 0.5 & 0 & 0.02 & 1.35 & 1.38 & 1.3 & 1.2 & 0.75 \\
\hline $\mathbf{A l}_{2} \mathbf{O}_{3}$ & 2.92 & 0.5 & 1.1 & 8.76 & 6.77 & 4.5 & 3.4 & 2.3 \\
\hline $\mathrm{Cr}_{2} \mathrm{O}_{3}$ & 0.16 & 0 & 0.14 & 0.15 & 0.18 & 0.14 & 0.16 & 0.21 \\
\hline FeO & 10.51 & 11.37 & 10.88 & 13.32 & 13 & 12.4 & 11.8 & 12.1 \\
\hline MnO & 0.16 & 0.48 & 0.1 & 0.15 & 0.12 & 0.13 & 0.11 & 0.67 \\
\hline MgO & 16.57 & 16.27 & 17.02 & 13.34 & 13.97 & 15.2 & 14.8 & 15.3 \\
\hline $\mathrm{CaO}$ & 12.39 & 12.92 & 13.29 & 12.64 & 12.57 & 12.3 & 12.6 & 12.4 \\
\hline $\mathrm{Na}_{2} \mathrm{O}$ & 0.59 & 0.12 & 0.12 & 1.65 & 0.82 & 0.13 & 0.56 & 0.5 \\
\hline $\mathbf{K}_{2} \mathrm{O}$ & 0.2 & 0.02 & 0 & 0 & 0.53 & 0.45 & 0.46 & 0.3 \\
\hline Total & 94.18 & 97.6 & 98 & 96.78 & 97.37 & 95.75 & 95.09 & 93.53 \\
\hline Cations & $24(0)$ & $24(0)$ & 24 (O) & $24(0)$ & $24(0)$ & $24(0)$ & $24(0)$ & $24(0)$ \\
\hline Si & 7.817 & 8.343 & 8.212 & 7.040 & 7.355 & 7.608 & 7.774 & 7.774 \\
\hline $\mathbf{T i}$ & 0.059 & 0 & 0.002 & 0.157 & 0.159 & 0.151 & 0.14 & 0.14 \\
\hline Al & 0.536 & 0.088 & 0.192 & 1.601 & 1.222 & 0.820 & 0.623 & 0.623 \\
\hline $\mathrm{Cr}$ & 0.02 & 0 & 0.016 & 0.018 & 0.022 & 0.017 & 0.02 & 0.02 \\
\hline $\mathrm{Fe}^{2+}$ & 1.369 & 1.419 & 1.35 & 1.727 & 1.665 & 1.604 & 1.534 & 1.534 \\
\hline Mn & 0.021 & 0.061 & 0.013 & 0.020 & 0.016 & 0.017 & 0.014 & 0.014 \\
\hline Mg & 3.847 & 3.618 & 3.765 & 3.082 & 3.188 & 3.503 & 3.429 & 3.429 \\
\hline $\mathrm{Ca}$ & 2.068 & 2.065 & 2.113 & 2.099 & 2.063 & 2.038 & 2.099 & 2.099 \\
\hline $\mathrm{Na}$ & 0.178 & 0.035 & 0.035 & 0.496 & 0.243 & 0.039 & 0.169 & 0.169 \\
\hline $\mathbf{K}$ & 0.04 & 0.004 & 0 & 0 & 0.104 & 0.089 & 0.091 & 0.091 \\
\hline Total & 15.955 & 15.632 & 15.699 & 16.241 & 16.037 & 15.886 & 15.894 & 15.894 \\
\hline
\end{tabular}
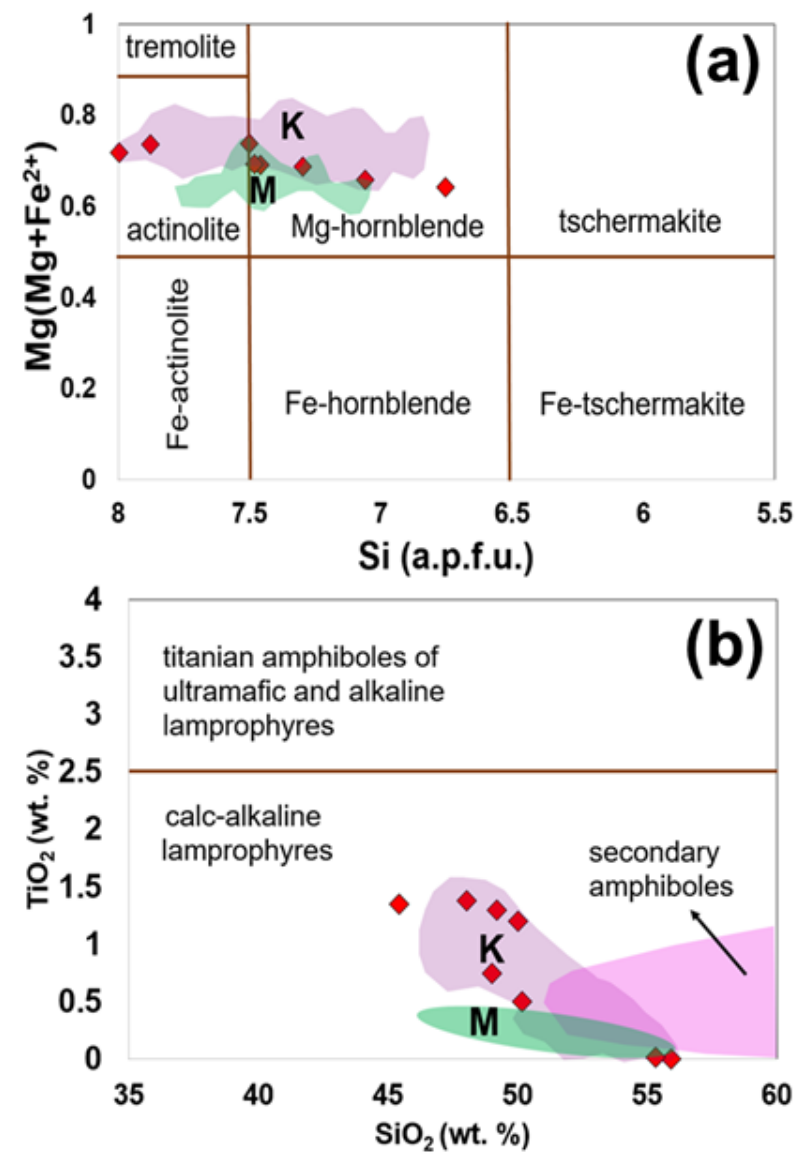

Figure 4

Classification of amphiboles in the KGL. (a) $\mathrm{Si}\left(\mathrm{apfu}\right.$ ) versus $\mathrm{Mg \#} \mathrm{plot} \mathrm{showing} \mathrm{magnesio-hornblende} \mathrm{nature.} \mathrm{(b)} \mathrm{SiO}_{2}$ versus $\mathrm{TiO}_{2}$ plot showing calc-alkaline character. Fields for Kadiri (K) and Mudigubba (M) lamprophyres are from RAGHUVAMSHI et al.

(2019). 
Table 4. Chemical composition of micas in the KGL.

\begin{tabular}{|c|c|c|c|c|c|c|c|}
\hline & Grain1 & Grain2 & Grain3 & Grain4 & Grain5 & Grain6 & Grain7 \\
\hline $\mathrm{SiO}_{2}$ & 34.84 & 35.45 & 34.15 & 33.43 & 31.33 & 32.5 & 33 \\
\hline $\mathrm{TiO}_{2}$ & 1.21 & 2.82 & 0.78 & 1.32 & 1.2 & 0.89 & 0.99 \\
\hline $\mathbf{A l}_{2} \mathbf{O}_{3}$ & 17.79 & 16.16 & 18.17 & 18.64 & 18.7 & 15.8 & 17.8 \\
\hline $\mathrm{FeO}$ & 21.44 & 19.69 & 21.21 & 21.97 & 20.4 & 21.3 & 22 \\
\hline MnO & 0.35 & 0.26 & 0.37 & 0.42 & 0.34 & 0.29 & 0.31 \\
\hline MgO & 9.32 & 9.67 & 9.18 & 8.68 & 8.7 & 8.6 & 9.2 \\
\hline $\mathrm{CaO}$ & 0.18 & 0.98 & 0.27 & 0.06 & 0.78 & 0.33 & 0.67 \\
\hline $\mathrm{Na}_{2} \mathrm{O}$ & 0.01 & 0 & 0.02 & 0.03 & 0.04 & 0.01 & 0.01 \\
\hline $\mathbf{K}_{2} \mathbf{O}$ & 9.71 & 9.55 & 9.67 & 9.31 & 8.79 & 9.54 & 9.44 \\
\hline Total & 94.85 & 94.58 & 93.82 & 93.86 & 90.28 & 89.26 & 93.42 \\
\hline Cations & 11(0) & 11(O) & 11(O) & 11(0) & 11(O) & 11(O) & 11(O) \\
\hline Si & 2.709 & 2.747 & 2.687 & 2.636 & 2.566 & 2.717 & 2.629 \\
\hline $\mathbf{T i}$ & 0.071 & 0.164 & 0.046 & 0.078 & 0.074 & 0.056 & 0.059 \\
\hline Al & 1.630 & 1.476 & 1.685 & 1.732 & 1.805 & 1.557 & 1.671 \\
\hline $\mathrm{Fe}^{+2}$ & 1.394 & 1.276 & 1.396 & 1.449 & 1.397 & 1.489 & 1.466 \\
\hline Mn & 0.023 & 0.017 & 0.025 & 0.028 & 0.024 & 0.021 & 0.021 \\
\hline Mg & 1.080 & 1.117 & 1.077 & 1.020 & 1.062 & 1.072 & 1.093 \\
\hline $\mathrm{Ca}^{\circ}$ & 0.015 & 0.081 & 0.023 & 0.005 & 0.068 & 0.030 & 0.057 \\
\hline $\mathbf{N a}$ & 0.002 & 0 & 0.003 & 0.005 & 0.006 & 0.002 & 0.002 \\
\hline $\mathbf{K}$ & 0.963 & 0.944 & 0.971 & 0.937 & 0.918 & 1.017 & 0.959 \\
\hline Total & 7.887 & 7.823 & 7.911 & 7.890 & 7.920 & 7.959 & 7.957 \\
\hline Mg\# & 0.437 & 0.467 & 0.436 & 0.413 & 0.432 & 0.419 & 0.427 \\
\hline
\end{tabular}
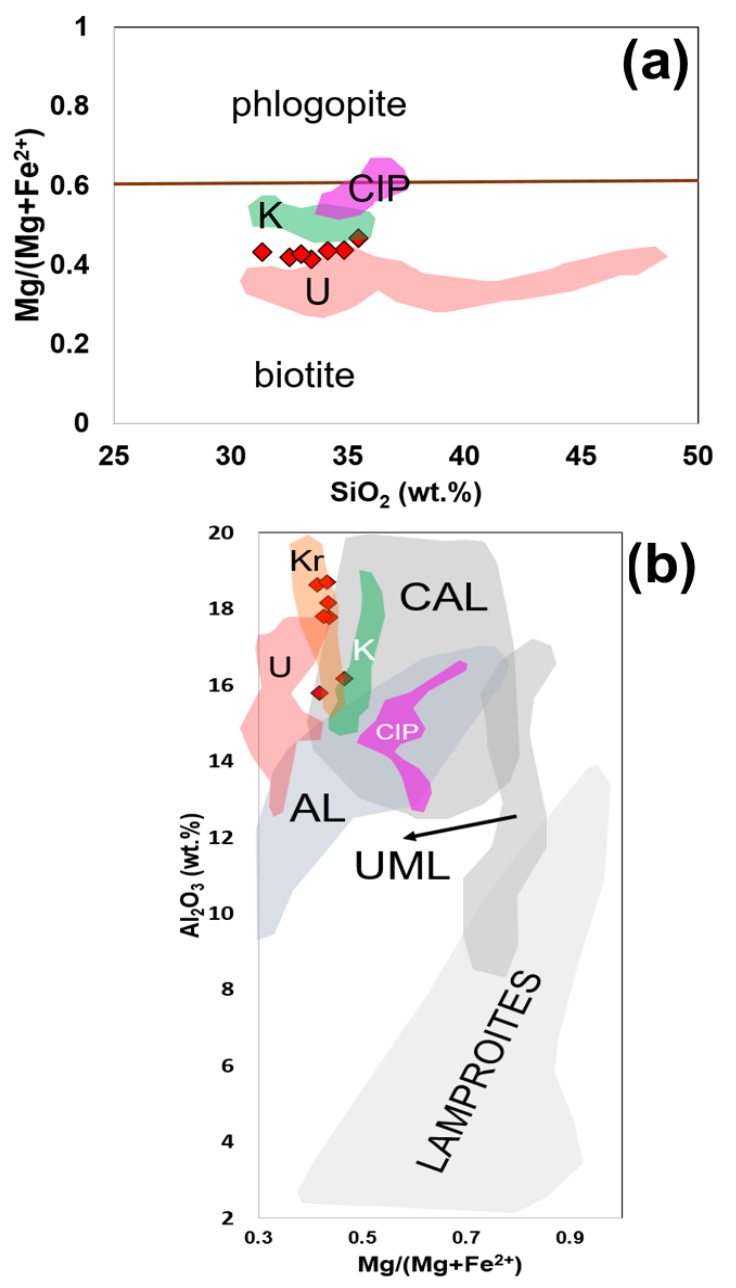

Figure 5

Classification of micas of the $\mathrm{KGL}$. (a) $\mathrm{SiO}_{2}$ versus $\mathrm{Mg} \#$ diagram showing biotitic nature. (b) $\mathrm{Mg} \#$ versus $\mathrm{Al}_{2} \mathrm{O}_{3}$ diagram distinguishing lamprophyre character based on micas. Abbreviations of lamprophyres: AL- alkaline, CAL- calc-alkaline, UMLultramafic. Fields for Cuddapah Intrusive Province (CIP), Kadiri (K), Karrakodu (Kr), Udiripikonda (U) are from PANDEY et al. 


\subsubsection{TITANATES}

Two types of titanites are identified in the KGL; an Al-rich variety (Fig. 6a and b) and a LREE and F-rich variety (Fig. 6c and d). These occur as irregular aggregates of $200 \mu \mathrm{m}$ and $100 \mu \mathrm{m}$ diameter, respectively. The latter type of titanite is the principal carrier of LREE such as $\mathrm{La}, \mathrm{Ce}$ and $\mathrm{Nd}$ in the KGL with 2.5, 3.4 and 1.2 at. $\%$ and $12.7,17.2$ and 6.3 Ox. \%,

\subsubsection{SULPHIDES AND OXIDES}

The sulphides in the KGL generally occur as products of hydrothermal activity. The sulphides include $\mathrm{Ni}$-free chalcopyrite and associated Ni-Co-As unidentified mineral phases (Fig. 6e and f). Magnetite is found to be intergrown with ilmenite associated with minor quantities of anhedral Ni-rich chalcopyrite and Ni-As-Co minerals. The order of abundance is magnetite $>$ ilmenite $>>$ chalcopyrite $>\mathrm{Ni}$-As-Co minerals. The presence of such sulphides is noticed in lamprophyres originated from mantle $(>100 \mathrm{~km})$ depths in subduction zones, continental rift settings and also as components

\subsubsection{OCELLAR CALCITE}

Ocellar calcite crystal aggregates of ovoidal to amoeboidal shape ubiquitously occur in the KGL. The calcite ocelli are bordered with plagioclase and biotite crystals in the peripheries forming coronitic structure (Fig.7a and $b$ ). No compositional anomalies were

\section{GEOCHEMISTRY AND PETROGENESIS}

The major element (Table 5), trace and rare earth element (REE) concentration data (Table 6) were used to decipher the geochemical and petrogenetic character of the KGL. The geochemical data have been plotted in various geochemical diagrams along with average values of other EDC lamprophyres. The KGL is characterised by lower $\mathrm{SiO}_{2}$ (41.8-43.7 wt. \%), lower $\mathrm{MgO}$ (6.8-7.6 wt. \%), than the nearby lamprophyres at Udiripikonda $\left(\mathrm{SiO}_{2} 45.2\right.$ and $\mathrm{MgO} 7.7$ wt. \%) and Kadiri $\left(\mathrm{SiO}_{2} 53.9\right.$ and $\mathrm{MgO}$ 8.5 wt. \%). The KGL samples show highly potassic (shoshonitic) character with $\mathrm{K}_{2} \mathrm{O} / \mathrm{NaO}$ ranging from 0.4-1.07. The $\mathrm{Al}_{2} \mathrm{O}_{3}$ and $\mathrm{TiO}_{2}$ concentrations range from $12.8-13.4$ wt. $\%$ and 1.9-2.8, respectively. The $\mathrm{CaO}$ in the KGL respectively. The $\mathrm{F}$ concentration is approximately estimated to be 10 at. \%. In general, the titanite crystallisation is generally favoured by $\mathrm{Ca}$-rich metaluminous oxidised melts that possess an intermediate $\mathrm{SiO}_{2}$ content (FROST et al. 2000). The titanites are partially transformed into leucoxene.

of bimodal dike suites as in the case of hydrothermal $\mathrm{Pb}-\mathrm{Zn}, \mathrm{Sb}-\mathrm{Hg}$, Ag-Sb deposits (ROCK 1991; MAUGHAN et al. 2002, SINCLAIR 2007). Euhedral xenocrystals of pyrite occur as individual crystals as well as crystal aggregates ubiquitously in the KGL (Fig. $6 \mathrm{~g}$ and $\mathrm{h}$ ). The pyrite crystals occasionally occur as twinned aggregates. The grain borders are slightly haematitised indicating oxidation as visualised in the spectra. However, the pyrite is found to be Asfree.

detected, however, feeble amounts of $\mathrm{Cl}(\sim 0.2$ at. \%) is noticed in the ocellar calcite. The mapping shows elements like $\mathrm{Mg}, \mathrm{Ca}, \mathrm{Si}, \mathrm{Al}$, $\mathrm{O}$ and $\mathrm{Na}$ (Fig.7a and b). The $\mathrm{Si}, \mathrm{Al}$ and $\mathrm{Na}$ are probably due to contamination from neighbouring silicate phases.

samples ranges from 6.88 to $7.66 \mathrm{wt}$. \% which is less than that of Udiripikonda (8.9 wt. \%) and Kadiri (8.6 wt. \%). The considerable $\mathrm{CaO}$ concentration is attributed to the presence of ubiquitous calcite ocelli. The The Mg\# of the KGL samples ranges from 77.2 to 78.9 . The KGL displays a similar average major element concentration similar to the lamprophyres of the EDC and elsewhere in the world. In case of metamorphosed lamprophyres where metamorphism has been over-printed by goldrelated alteration and deformation synchronous with gold deposition, the diagnostic textures are difficult to be detected. Nevertheless, their unique chemical composition still persists, as has also been indicated by Perring et al. (1989). 

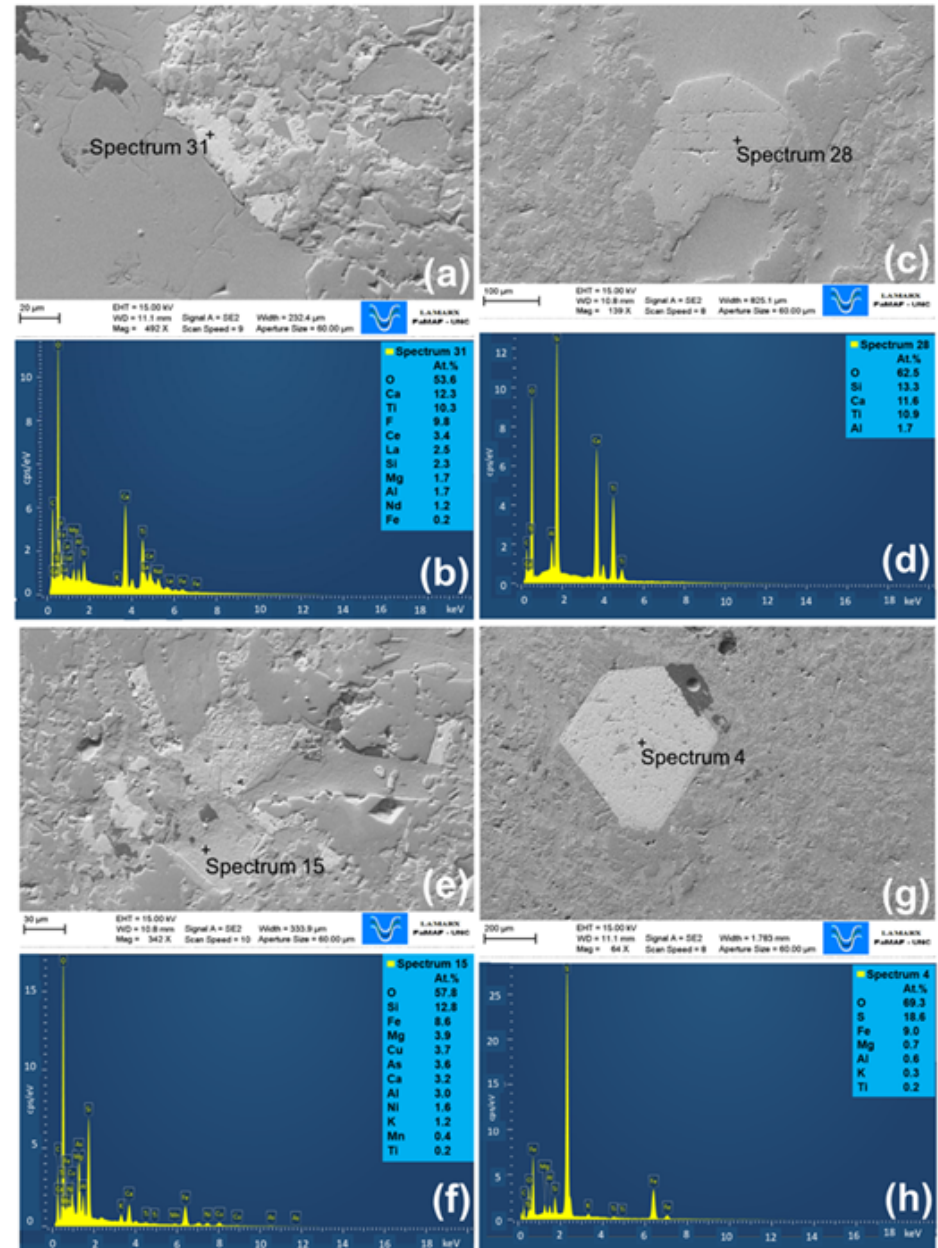

Figure 6

SEM-EDS photographs and Energy Dispersive X-ray spectra of certain accessory minerals in the Kallagalla lamprophyre. (a) and (b) LREE rich titanite with spectra showing peaks of LREE ( $\mathrm{La}, \mathrm{Ce}$ and $\mathrm{Nd}$ ). (c) and (d) Euhedral Al- rich titanite showing peaks of Al. (e) and (f) Unidentified Ni-Co-As sulphides. Oxygen peaks are not of sulphides but from the surrounding silicate phase. (g) and (h) Well developed crystal of pyrite and its corresponding EDS spectra.

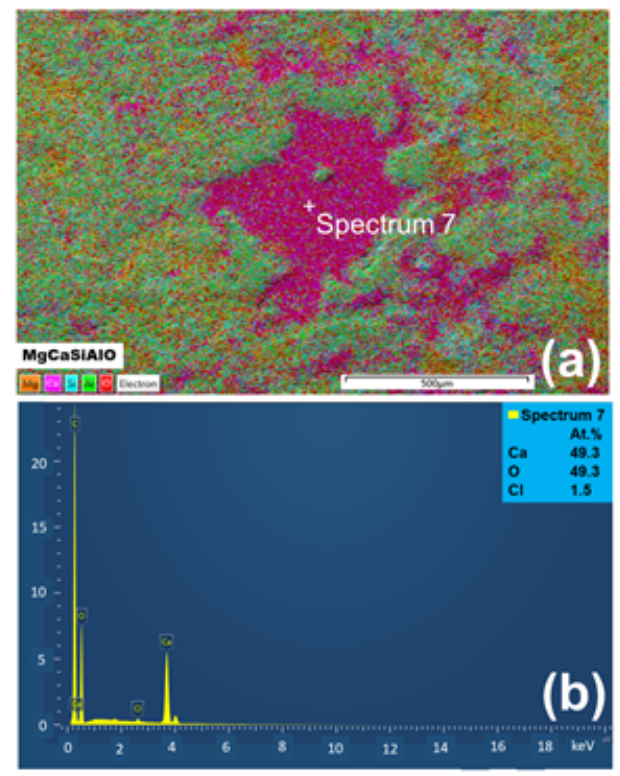

Figure 7

SEM-EDS photograph showing (a) spatial distribution of elements in ocellar calcite. Mg (orange), $\mathrm{Ca}$ (pink), Si (cyan), Al (green) and $\mathrm{O}$ (red). (b) EDS spectra of ocellar calcite. 
Table 5 - Whole rock major element analysis (wt.\%) and normative geochemical indices of the Kalagalla lamprophyre.

\begin{tabular}{|c|c|c|c|c|c|c|}
\hline Sample\# & SML01 & SML02 & SML03 & SML04 & SML05 & SML06 \\
\hline $\mathrm{SiO}_{2}$ & 42.8 & 42.8 & 41.7 & 41.87 & 42.66 & 42.5 \\
\hline $\mathrm{TiO}_{2}$ & 1.18 & 1.2 & 1.2 & 1.4 & 1.4 & 1.8 \\
\hline $\mathrm{Al}_{2} \mathrm{O}_{3}$ & 9.02 & 11.8 & 12.2 & 10.3 & 10.25 & 11.3 \\
\hline $\mathrm{Fe}_{2} \mathrm{O}_{3}$ & 10.6 & 9.5 & 11.01 & 10.56 & 9.97 & 9.95 \\
\hline $\mathrm{FeO}$ & 9.55 & 8.72 & 9.9 & 9.1 & 8.96 & 8.95 \\
\hline MnO & 0.18 & 0.17 & 0.17 & 0.19 & 0.19 & 0.21 \\
\hline MgO & 7.5 & 6.79 & 7.65 & 6.6 & 6.5 & 6.44 \\
\hline $\mathrm{CaO}$ & 6.25 & 6.6 & 5.78 & 6.66 & 5.43 & 6.46 \\
\hline $\mathrm{Na}_{2} \mathrm{O}$ & 1.1 & 0.9 & 0.89 & 1.75 & 1.23 & 0.89 \\
\hline $\mathrm{K}_{2} \mathrm{O}$ & 2.73 & 3 & 2.6 & 2.71 & 2.88 & 2.77 \\
\hline $\mathbf{P}_{2} \mathrm{O}_{5}$ & 0.43 & 0.5 & 0.44 & 0.48 & 0.52 & 0.58 \\
\hline LOI & 8.52 & 7.87 & 6.33 & 8.4 & 8.44 & 7.89 \\
\hline Total & 99.83 & 99.79 & 99.8 & 99.99 & 98.47 & 99.72 \\
\hline $\mathrm{Fe}^{3+} /\left(\mathrm{Fe}_{\mathrm{t}}\right)$ & 50 & 49.5 & 50 & 51.1 & 50 & 50 \\
\hline Mg\# & 77.4 & 77.5 & 77.2 & 78.2 & 77.5 & 78.9 \\
\hline $\mathrm{Ca} /(\mathrm{Ca}+\mathrm{Na})$ & 75.8 & 80.5 & 78.2 & 67.8 & 70.9 & 80 \\
\hline Plagioclase An content & 53.6 & 70.6 & 72.8 & 43.1 & 55.1 & 69.2 \\
\hline Differentiation Index & 39.9 & 47 & 46 & 43.4 & 45.1 & 46.8 \\
\hline
\end{tabular}

Table 6. Whole rock trace and rare earth element (REE) analyses of the Kalagalla lamprophyre (ppm).

\begin{tabular}{|c|c|c|c|c|c|c|}
\hline Sample\# & KLG01 & KLG02 & KLG03 & KLG04 & KLG05 & KLG06 \\
\hline $\mathrm{Sc}$ & 17.09 & 16.4 & 15.8 & 15.5 & 18.02 & 18.1 \\
\hline $\mathrm{V}$ & 147.1 & 133 & 121 & 145 & 144.3 & 123.1 \\
\hline $\mathrm{Cr}$ & 400 & 470 & 400 & 400 & 380 & 470 \\
\hline $\mathrm{Co}$ & 49.62 & 48.7 & 48.9 & 46.9 & 50.12 & 49.4 \\
\hline $\mathrm{Ni}$ & 159.86 & 159.7 & 162.3 & 160.1 & 158.5 & 153.5 \\
\hline $\mathrm{Cu}$ & 60.02 & 57 & 62 & 61.3 & 60.4 & 59.44 \\
\hline $\mathrm{Zn}$ & 110 & 98 & 102 & 104 & 98.9 & 96 \\
\hline $\mathrm{Ga}$ & 12.3 & 11.3 & 12.6 & 12.9 & 12.4 & 11.56 \\
\hline $\mathrm{Rb}$ & 86.81 & 87.8 & 87.6 & 86.3 & 85.8 & 86.5 \\
\hline $\mathrm{Sr}$ & 883.09 & 887.5 & 885.6 & 779.4 & 745 & 834.65 \\
\hline $\mathrm{Y}$ & 17.3 & 12.5 & 15.7 & 17.04 & 14.76 & 15.6 \\
\hline $\mathrm{Zr}$ & 335 & 332 & 267 & 289 & 331.2 & 332.8 \\
\hline $\mathrm{Nb}$ & 35.7 & 34.6 & 35.8 & 37.6 & 34.9 & 38.9 \\
\hline $\mathrm{Ba}$ & 500 & 900 & 900 & 900 & 900 & 1700 \\
\hline Hf & 1.68 & 1.76 & 1.4 & 1.77 & 1.89 & 1.65 \\
\hline $\mathrm{Ta}$ & 2.01 & 1.89 & 1.94 & 2.04 & 2.3 & 1.94 \\
\hline $\mathrm{Pb}$ & 6.14 & 5.8 & 6 & 5.44 & 6.21 & 6.02 \\
\hline $\mathrm{Th}$ & 3.13 & 2.89 & 2.78 & 2.67 & 3.1 & 3.03 \\
\hline $\mathrm{U}$ & 0.5 & 0.4 & 0.6 & 0.45 & 0.44 & 0.43 \\
\hline Sample\# & KLG01 & KLG02 & KLG03 & KLG04 & KLG05 & KLG06 \\
\hline $\mathrm{La}$ & 75.04 & 81.2 & 75.6 & 79.4 & 83.02 & 77.8 \\
\hline $\mathrm{Ce}$ & 152.08 & 146.8 & 154.3 & 151.44 & 148.4 & 149.4 \\
\hline $\mathrm{Pr}$ & 17.76 & 16.8 & 18.7 & 17.6 & 18.43 & 12.6 \\
\hline $\mathrm{Nd}$ & 62.45 & 58.9 & 45.7 & 58.9 & 62.3 & 56.8 \\
\hline $\mathrm{Sm}$ & 9.87 & 8.9 & 9.4 & 10.1 & 11.11 & 9.98 \\
\hline $\mathrm{Eu}$ & 2.69 & 2.76 & 1.98 & 2.65 & 2.87 & 2.77 \\
\hline $\mathrm{Gd}$ & 8.49 & 7.89 & 8.54 & 8.44 & 8.5 & 7.89 \\
\hline Dy & 0.94 & 1.4 & 1.1 & 0.98 & 1.3 & 1.02 \\
\hline $\mathrm{Er}$ & 4.22 & 3.88 & 4.2 & 3.98 & 3.77 & 4.18 \\
\hline $\mathrm{Yb}$ & 1.3 & 1.2 & 1.4 & 1.25 & 1.35 & 1.4 \\
\hline $\mathrm{Tb}$ & 0.94 & 1.01 & 1.1 & 1.2 & 0.95 & 0.95 \\
\hline Ho & 0.67 & 0.71 & 0.73 & 0.65 & 0.73 & 0.62 \\
\hline $\mathrm{Tm}$ & 0.19 & 0.21 & 2 & 0.18 & 0.17 & 0.22 \\
\hline $\mathrm{Lu}$ & 0.17 & 0.17 & 0.18 & 0.22 & 0.21 & 0.17 \\
\hline$\Sigma \mathrm{REE}$ & 336.79 & 331.83 & 324.93 & 336.99 & 343.11 & 325.8 \\
\hline
\end{tabular}


In the $\mathrm{Al}_{2} \mathrm{O}_{3}-\mathrm{Fe}_{2} \mathrm{O}_{3}-\mathrm{MgO}$ ternary diagram, the KGL samples plot in the field designated for lamprophyres (Fig.8a). The calc-alkaline character of the KGL samples is clearly evident in the $\mathrm{SiO}_{2}$ and $\mathrm{TiO}_{2}$ diagram with similarities in geochemical character to other EDC lamprophyres taken for comparison (Fig.8b). The $\mathrm{SiO}_{2} / 10-\mathrm{CaO}-\mathrm{TiO}_{2} * 4$ ternary diagram displays evident compositional affinity with calc-alkaline rocks (Fig.8c). The calc-alkaline character of the KGL samples is also reflected by the $\mathrm{TiO}_{2}-\mathrm{Al}_{2} \mathrm{O}_{3}$ diagram (Fig.8d). As a general phenomenon, the calcalkaline magmatism reflects the chemical heterogeneity in the mantle caused by reequilibration of sediments and oceanic crust interacting through subduction and provides a unique prospect to study crust-mantle interactions (STERN 2002). This concept appears to be true in case of KGL samples.
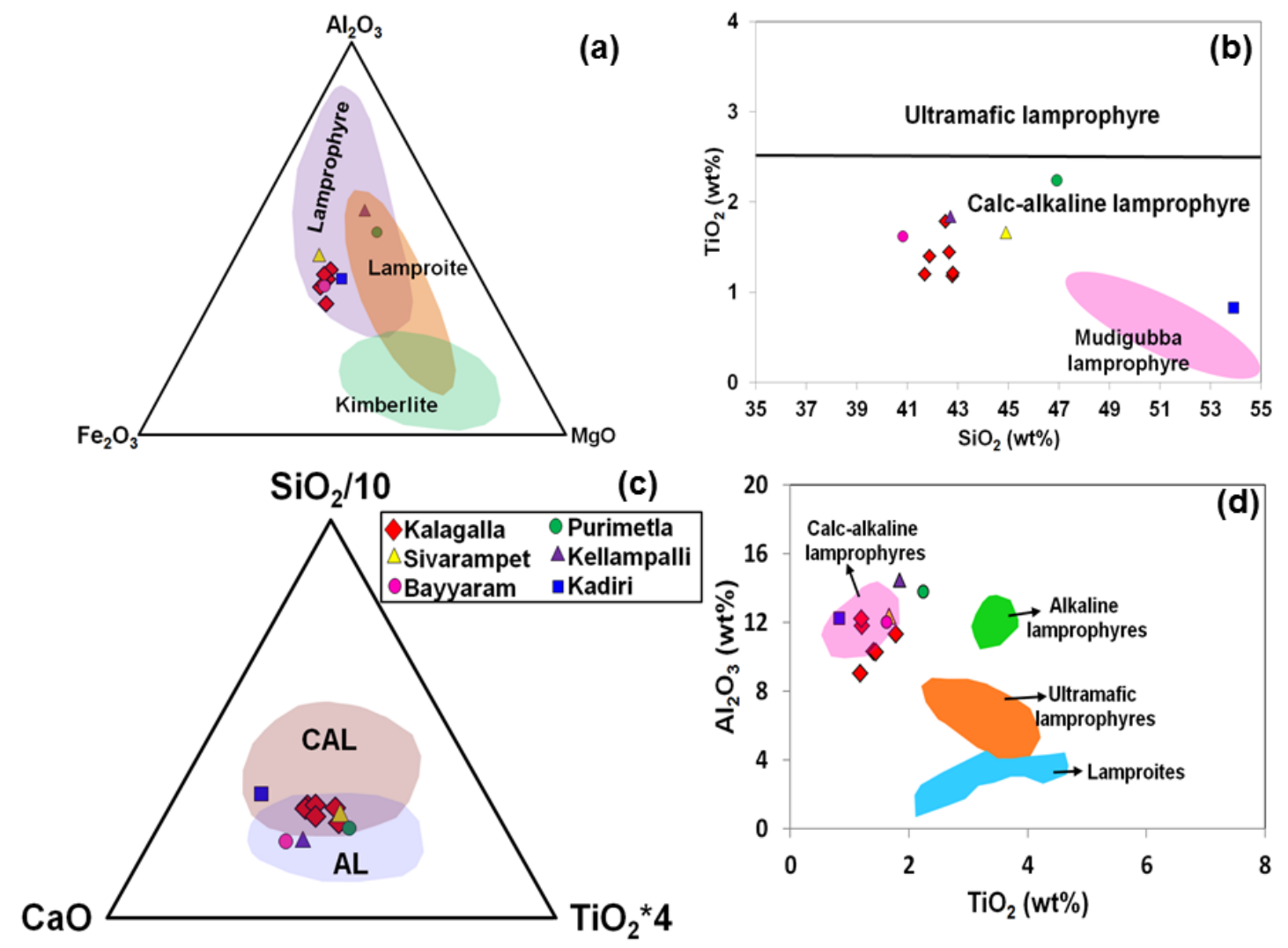

Figure 8

Major element variations of the Kalagalla lamprophyre in comparison with other occurrences of the Eastern Dharwar Craton. (a) $\mathrm{Fe}_{2} \mathrm{O}_{3}-\mathrm{Al}_{2} \mathrm{O}_{3}-\mathrm{MgO}$ (CORNELISSEN; VERWOERD 1975; KORNPROBST 1984). (b) $\mathrm{SiO}_{2}$ versus $\mathrm{TiO}_{2}(\mathrm{ROCK}$ 1991). Field for Mudigubba is taken from PANDEY et al. (2017). (c) $\mathrm{SiO}_{2}-\mathrm{CaO}-\mathrm{TiO}_{2}$ (ROCK 1987). (d) $\mathrm{TiO}_{2}$ versus $\mathrm{Al}_{2} \mathrm{O}_{3}(\mathrm{LEFEBVRE}$ et al.

2005).

The KGL samples exhibit shoshonitic character evidenced by various geochemical diagrams plotted using certain major elements. In the $\mathrm{Na}_{2} \mathrm{O}$ versus $\mathrm{K}_{2} \mathrm{O}$ diagram, the $\mathrm{KGL}$ samples show shoshonitic character like other lamprophyres. The Bayyaram and Kadiri lamprophyres show ultrapotassic and calcalkaline character, respectively (Fig.9a). The shoshonitic affinity of the KGL samples is also supported by the $\mathrm{SiO}_{2}$ versus $\mathrm{K}_{2} \mathrm{O}$ diagram, which is consistent with that of lamprophyres of other areas. Although the KGL samples plot in the shoshonite field, they are close to the high calc-alkaline, high potassic region (Fig. $9 b$ ). Further, the shoshonitic character is also supported by the biotite compositions. In the bivariate diagram involving $\mathrm{SiO}_{2}$ and total alkali $\left(\mathrm{Na}_{2} \mathrm{O}+\mathrm{K}_{2} \mathrm{O}\right)$, the majority of the KGL samples straddle over the alkaline field (Fig. $9 \mathrm{c})$. The high potassic nature of the KGL samples is evidenced in the geochemical diagram of $\mathrm{MgO}$ versus $\mathrm{K}_{2} \mathrm{O}$ (Fig.9d). 

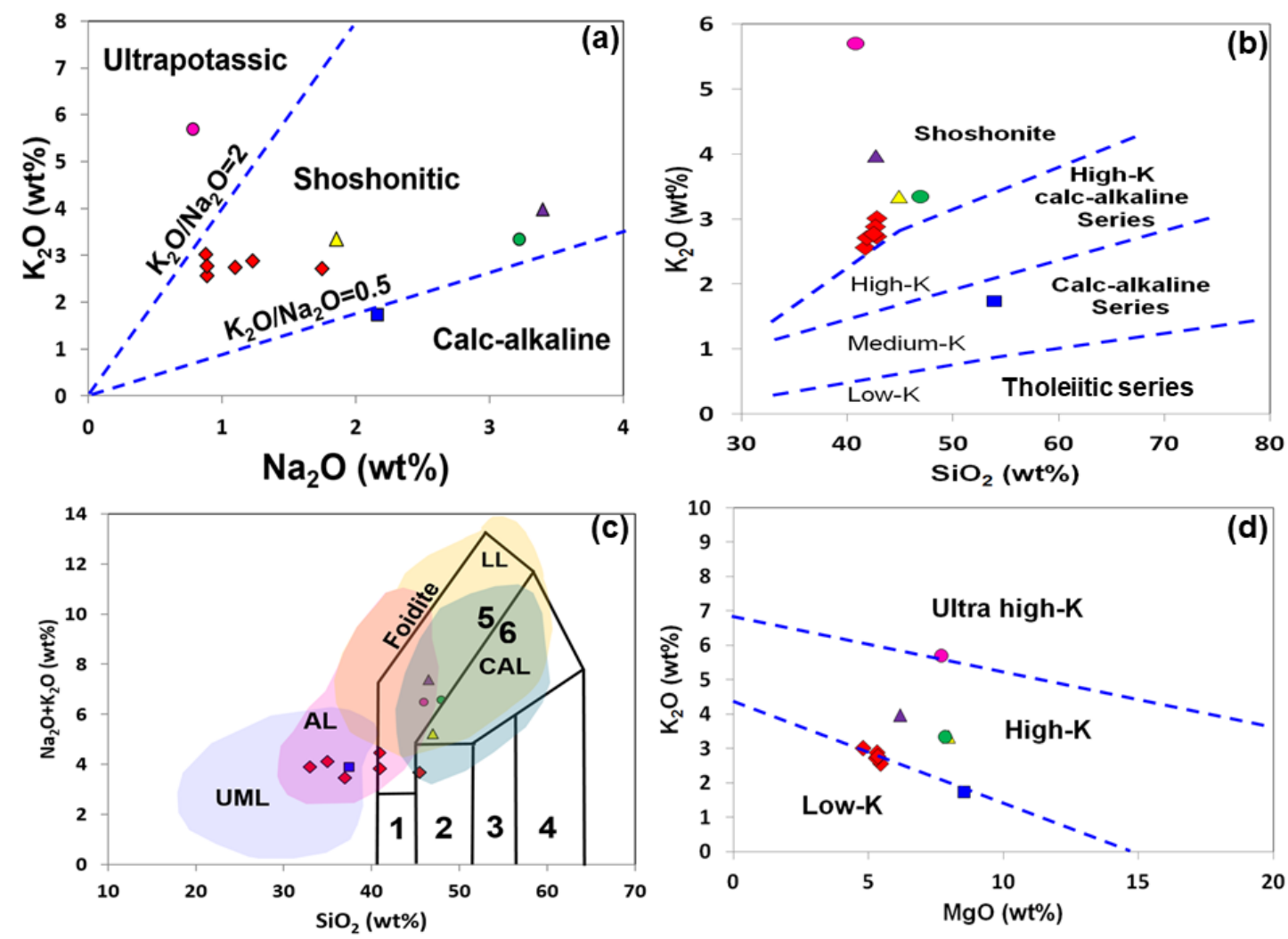

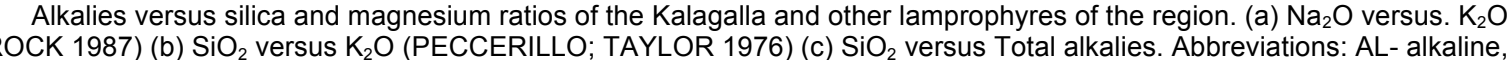
UML- ultramafic, CAL- calc-alkaline lamprophyres; 1- picrobasalt, 2- basalt, 3- basaltic andesite, 4- andesite, 5- basanite, 6trachyandesite (ROCK 1987). (d) MgO versus $\mathrm{K}_{2} \mathrm{O}$ (PECCERILLO; TAYLOR 1976). Symbols as in Figure 8.

The increased values for $\mathrm{Ba}, \mathrm{Rb}, \mathrm{Sr}, \mathrm{K}, \mathrm{Rb}$, $\mathrm{Zr}$, Ti and $\mathrm{Y}$ with depleted $\mathrm{Nb}$ in the KGL samples demonstrates their calc-alkaline character, as seen in the Archaean metalamprophyre of Nuggihalli Schist Belt of the Dharwar craton (SUGAVANAM et al. 1994). The concentrations of LILE (large ion lithophile elements) are relatively high in the KGL samples. The Ba concentration in KGL samples is high and ranges from 500 to 1700 ppm while Sr ranges from 745 to $887 \mathrm{ppm}$. $\mathrm{The} \mathrm{Ba} / \mathrm{Nb}(\sim 14$ to $44 \mathrm{ppm})$ and $\mathrm{Ba} / \mathrm{La}(\sim 11$ to 22) ratios, except for the sample KLG01 $(\mathrm{Ba} / \mathrm{La} \sim 7 \mathrm{ppm})$ are high indicating a mantle source (RYAN et al. 1996; KEPEZHINSKAS et al. 2016). Lamprophyre intrusions act as geotectonic markers and offer clues on the geodynamic evolution (SCARROW et al. 2011). The HFSE (high field strength elements) are indicators of arc related magmatism or subduction modified lithospheric mantle (WILSON, 1989; PEARCE 2008). In majority, the lamprophyres associated with the greenstone belts in the Archaean terrains show shoshonitic affinity highlighting a major role of subduction processes in development and evolution of greenstone belts (PANDEY et al. 2018). In the KGL samples, the enriched ratios of $\mathrm{Nb} / \mathrm{U}$ $(\sim 60-90.5) \quad \mathrm{Nb} / \mathrm{Ta}(\sim 15-20) \mathrm{Zr} / \mathrm{Hf}(163-202)$ also correspond to enriched mantle sources (HOFMANN et al. 1986; SUN; MCDONOUGH 1989; STOLZ et al. 1996). The high proportion $\mathrm{Nb} / \mathrm{U}$ in KGL samples can be attributed to the depletion of $U$ at the source. $\mathrm{The} \mathrm{Nb} / \mathrm{U}$ ratio in MORB and OIB is $47 \pm 7$ (HOFMANN et al. 1986) and in the upper and lower crust it is approximately 4.5 and 25, respectively (RUDNICK; GAO 2003). However, the subduction hydrous fluids possess a very low $\mathrm{Nb} / \mathrm{U}$ ratio of 0.22 (AYER $1998)$. Therefore, the $\mathrm{Nb} / \mathrm{U}$ ratio ( $60-90)$ in the KGL supports its mantle origin similar to MORB and OIB. The lamprophyre is characterized by the abundance of Ni (153-162 ppm), $\mathrm{Cr}(380-470 \mathrm{ppm})$ and $\mathrm{MgO}$ ( 6.5-7.6 wt. \%) which indicates a mantle source (e.g. FREY et al. 1978). Furthermore, the depletion of $\mathrm{TiO}_{2}\left(1.2-1.8\right.$ wt. \%) and $\mathrm{Al}_{2} \mathrm{O}_{3}(9.02-11.8$ wt. \%) in the KGL along with enrichment of LILE infer a depleted mantle source that underwent an earlier event of partial melting 
during the continental crust formation which probably was later modified by the addition of LILE with respect to HFSE through subduction process. Such a conspicuous depletion in HFSE is resultant of Ti-bearing residual phase in the mantle. This is also supported by the occurrence of a Ti-rich minerals like ilmenite, rutile-rich mantle xenoliths (e.g. eclogite) in the kimberlites of the WKF (CHALAPATHI RAO et al. 2004; PATEL et al. 2009; DONGRE et al. 2015). The presence of ilmenite as an accessory phase in the KGL is consistent with this concept.

The HFSE/LREE ratio indicates the mantle origin (SMITH et al. 1999). This is supported by the $\mathrm{Nb} / \mathrm{La}$ ratio of the KGL ranging from 0.42 to 0.5 , which indicates its origin from a lithospheric mantle $(\mathrm{Nb} / \mathrm{La}<0.5)$ rather than an OIB like asthenospheric mantle $(\mathrm{Nb} / \mathrm{La}>1)$. The KGL samples show coherent step-like chondrite normalised patterns with enrichment of LREE and depletion of HREE (heavy rare earth elements). It is evident that the REE concentration in the KGL are depleted when compared to that in the other lamprophyres. The lack of Eu anomaly indicates the absence of plagioclase fractionation. Factors such as a generalised inclined REE pattern (LREE>HREE), LREE-bearing leucoxene after titanites present in the groundmass, indicate involvement of residual garnet during melting. Enrichment of LREE and depletion of HREE and a regular decrease from $\mathrm{La}$ to $\mathrm{Lu}$ is similar to the REE character of lamprophyres of the CIP with exceptions of lows at Dy, Yb and Ho (Fig. 10a). The primitive mantle normalized HFSE/LREE variation, exemplified by $\mathrm{Ta} / \mathrm{La}$ versus $\mathrm{Hf} / \mathrm{Sm}$ plot, provides inference that the mantle source of the KGL samples was modified by fluid related subduction metasomatism (Fig. 10b). In the $\mathrm{La} / \mathrm{Nb}-\mathrm{Ba} / \mathrm{Nb}$ bivariate diagram, the KGL samples plot very close to the array of subduction enrichment (Fig.10c). The $\mathrm{Rb} / \mathrm{Sr}$ ratios also support a subduction tectonic environment. The enrichment of volatiles $\left(\mathrm{CO}_{2}, \mathrm{H}, \mathrm{F}, \mathrm{Cl}\right.$, etc. $)$ in lamprophyres might be due to the presence of hydrous mineral phases such as amphibole, phlogopite and apatite and titanite partially transformed into leucoxene. All these mineral phases are produced from metasomatic processes (FOLEY 1992; BATKI et al. 2014). In general, $\mathrm{Rb}$ is retained by phlogopite more easily than Sr. Similarly, Ba more than Rb is hosted in amphiboles. Consequently, a rise by $\mathrm{Rb} / \mathrm{Sr}$ ratio will lead to the entry of phlogopite phase whilst a rise in $\mathrm{Ba} / \mathrm{Rb}$ indicates the involvement of amphiboles as the prevailing hydrous mineral phase (FURMAN; GRAHAM 1999). Thus the KGL samples show dominance of a phlogopite-rich source in the mantle reservoir (Fig.10d). This is consistent with other nearby lamprophyres such as Udiripikonda and Sivarampet (PANDEY et al. 2018; KHAN et al. 2018) indicating a similar magmatic composition at the source for lamprophyres of this region. In addition, emplacement of diamondiferous kimberlites, lamprophyres and alkali syenites within the Wajrakarur kimberlite field suggests an entirely heterogenous mantle of different compositions beneath this part of the EDC (RAGHUVAMSHI et al. 2019). Despite metamorphism, the characteristic chemistry of the lamprophyres persists in the KGL in terms of higher concentrations of $\mathrm{Sr}, \mathrm{Rb}, \mathrm{Pb}, \mathrm{Ba}$ and Ce.

Globular ocelli of carbonate or felsic silicate aggregates are common features of lamprophyres and some alkali basalts (e.g. PHILLPOTTS, 1990; ROCK,1991, AZBEJ et al. 2006). The ocelli are inferred to be the products of (i) silicate-carbonate (ii) silicatesilicate liquid immiscibility or (iii) latestage/secondary vesicle filling i.e. amygdales (e.g., VICHI et al., 2005). The origin of primary carbonate globular aggregates in the $\mathrm{KGL}$ is thought to be due to late stage silicatecarbonate liquid immiscibility mechanism or late stage melt segregation which can give rise to their presence in the lamprophyre magma (COOPER 1979; HAMILTON et al. 1979; FOLEY 1984; VICHI et al. 2005; MITCHELL 2005; TAPPE et al. 2006). Although it is speculative whether the KGL carbonate aggregates are primary or secondary, the presence of discrete calcite/carbonate ocellar crystal aggregates stand as an example of its magmatic origin rather than carbonate filled vesicles. Further, the carbonate ocelli are intimately associated with biotite and plagioclase crystals reflecting their magmatic character. The biotites of the groundmass and that with the carbonate ocelli strikingly show similar composition. If carbonate ocelli are formed earlier than the groundamss, both biotite and plagioclase should be less evolved in terms of $\mathrm{Fe} / \mathrm{Mg}$ and $\mathrm{Ca} / \mathrm{Na}$ ratios. The plagioclase in the carbonate ocelli is slightly richer in molar An than that in the groundmass, which clearly supports the magmatic origin of the carbonate ocelli. The occurrence of 
carbonate ocelli is not an unusual case; similar observations were made in Jungel and Chitrangi lamprophyres in Mahakoshal supracrustal belt (SRIVASTAVA; CHALAPATHI RAO 2007; SRIVASTAVA 2013). In addition, the high $\mathrm{Zr} / \mathrm{Hf}$ ratios in the KGL samples also suggest primary carbonate involvement at the source (CONTICELLI et al. 2015; TAPPE et al. 2016; TAPPE et al. 2017; RAGHUVAMSHI et al. 2019). The $\mathrm{Zr} / \mathrm{Hf}$ ratios in the KGL samples are much higher ( 163-201) than the normal continental crust ( $\sim 36)$ clearly supporting absence of crustal contamination (RUDNICK; GAO 2003).

The KGL also contains numerous grains of sulphide minerals. The pyrite crystals possess a thin outline of haematite. It should be noted that certain trace elements in sulphide minerals are used as indicators of origin and environment of ore formation (BRALIA et al. 1979, BAJWAH et al. 1987; KOUHESTANI et al. 2017). An occurrence of cobaltoan pyrite and its genetic significance was testified in lamprophyres of Mahakoshal belt (GIRI et al. 2018). Hence, a detailed study is warranted on the sulphide minerals present in the KGL to obtain information not only on the petrogenesis of this lamprophyre but also about its paragenetic association with auriferous lodes in the RPSB. Despite the limited number of analyses presented in this contribution, consistency of data allowed to infer certain petrogenetic aspects of the KGL. From the field, petrographic, mineralogic and geochemical investigations, a plausible petrogenetic model for the KGL intrusion would involve the presence of a garnetiferous lithospheric mantle with enriched LILE and a phlogopite-bearing metasomatic event which interacted with carbonated silicate melts. Further investigations are certainly warranted to delineate tectonomagmatic origin of this lamprophyre and its association with auriferous schist belt in contributing to the evolution of the Dharwar craton.
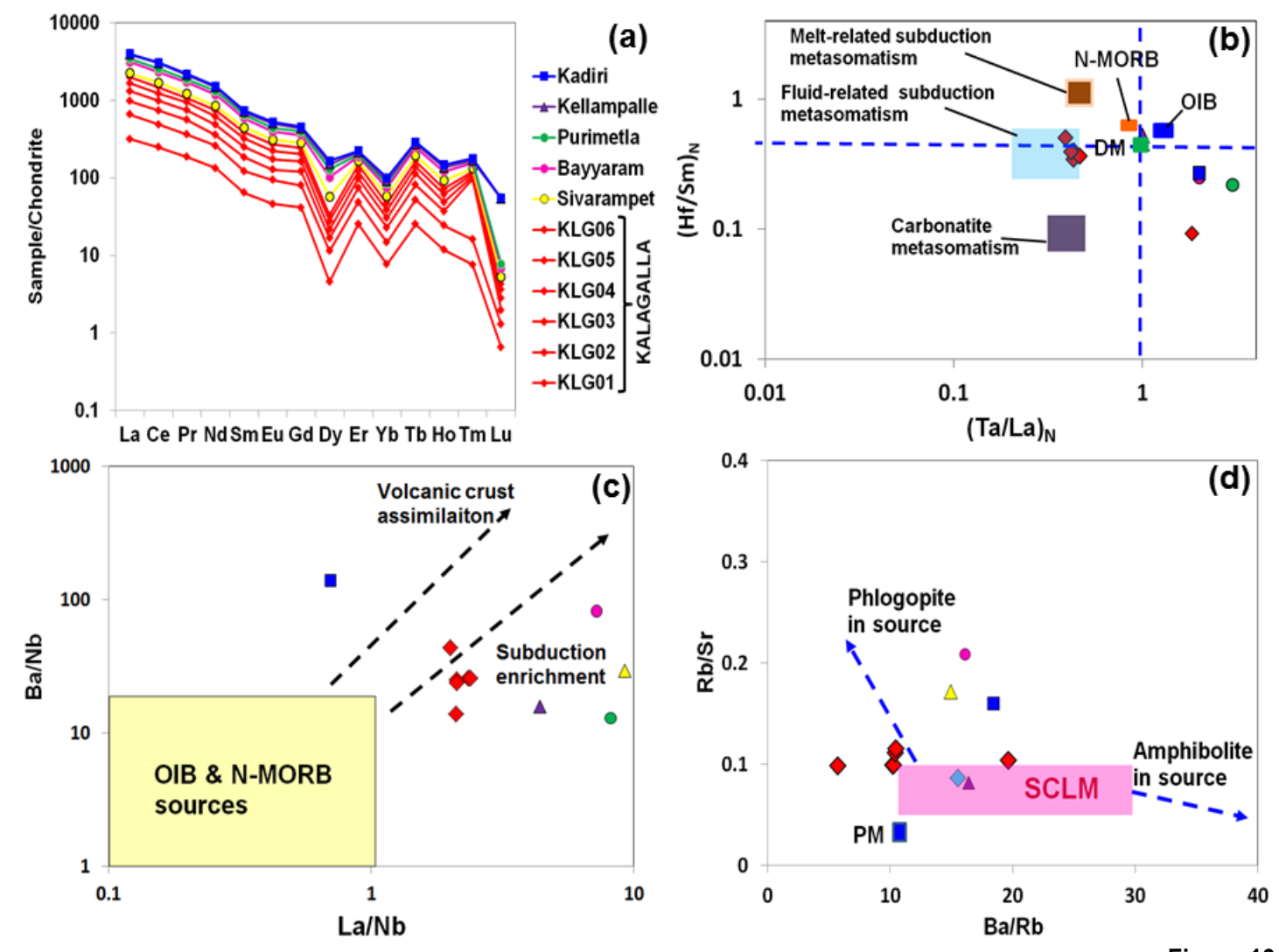

Figure 10

Geochemical and tectonic discrimination diagrams of the Kalagalla lamprophyre in comparison with other occurrences. (a) Chondrite normalized REE patterns (SUN; MCDONOUGH 1989). (b) Primitive mantle normalised (SUN; MCDONOUGH 1989)

$\mathrm{Ta} / \mathrm{La}$ vs. Hf/Sm (JOHNSON; PLANK 2000) (c) La/Nb versus Ba/Nb (KEPEZHINSKAS et al. 2016). (d) Ba/Rb versus Rb/Sr 


\section{CONCLUSIONS}

Preliminary investigations of the metalamprophyre at Kalagalla (KGL), emplaced within the auriferous RamagiriPenakacherla Schist Belt, show geochemical and petrological similarities with other lamprophyres of the EDC. The rock is sheared, at places chloritised along foliated planes and also actinolitised. The KGL comprises magnesio-hornblende, biotite, plagioclase $\left(\mathrm{Or}_{1.84} \mathrm{Ab}_{86.26} \mathrm{An}_{11.90}\right)$, and calcite ocelli as prominent minerals and phlogopite, apatite, zircon as minor minerals. The opaque phases such as magnetite, ilmenite, As-free pyrite, $\mathrm{Ni}$ bearing chalcopyrite associated with $\mathrm{Ni}$-As-Co minerals, LREE (Fe)-bearing titanite partially replaced by leucoxene occur as accessory phases as observed in the SEM-EDS studies. The calcite ocelli show no anomalies in their chemistry. The plagioclase in the carbonate ocelli is slightly richer in molar An than that in the groundmass, which clearly supports the magmatic origin of the carbonate ocelli. The KGL shows porphyritic and nematogranoblastic textures owing to metamorphism, yet the ocelli texture is preserved. The aphanitic texture, masked by metamorphic textures, makes the KGL challenging to identify its type; however, its mineral chemistry and geochemical character clearly establish its calc-alkaline nature in general and classify it as a spessartite variety in particular with absence of crustal contamination. The

\section{ACKNOWLEDGEMENTS}

PRCP thanks Cyient Limited for extending all necessary support during the initial stage of Covid-19 lockdown. Prof. Madabhooshi Srinivas, former Head, Department of Geology, Osmania University, Hyderabad is thanked for the petrological research microscope facility. The authors acknowledge the use of SEM-EDS and EPMA

\section{REFERENCES}

ADHIKARY D., SAHOO R., BEHARA K.K. 2017. New finding alkaline lamprophyre dykes cluster in the Western margin of the Proterozoic Pakhal basin in and around Khammam, Telangana, India: Evidence of alkaline magmatism. In: XXXIV International Conference on "Magmatism of the Earth and related strategic metal deposits, Russia, $3 p$. ubiquitously present ocelli are made up of crystalline calcite bordered by plagioclase $\left(\mathrm{Or}_{0.86} \mathrm{Ab}_{82.01} \mathrm{An}_{17.13}\right)$ and biotite crystals showing coronitic and sometimes glomeroporphyiritic texture. Rarely the ocelli are made up of biotite and ilmenite. The shoshonitic affinity is well demonstrated by its geochemical character. The trace element variations indicate its association with the subduction environment. The enrichment of LREE is most likely attributed to the presence of LREE-bearing titanite partially transformed into leucoxene. The REE pattern (LREE>HREE) indicates involvement of residual garnet during melting. The absence of $\mathrm{Eu}$ anomaly demonstrates lack of plagioclase fractionation. The KGL geochemistry displays involvement of carbonate at the source to form ocellar aggregates due to late-stage liquid carbonate-silicate immiscibility or segregation process and also lack of crustal contamination, supported by high $\mathrm{Zr} / \mathrm{Hf}$ ratios. The occurrence of several lamprophyric intrusions in close spatial and temporal association with diamondiferous kimberlites in this WKF region indicates a highly heterogeneous mantle beneath this part of the craton. This lamprophyre undeniably deserves further study to understand its role on the magmatic events in WKF-RPSB domain and chronological crustal evolution in the Dharwar Craton at a larger scale.

facilities at the Laboratory of Electron Microscopy and X-ray Analysis (LAMARX), Faculty of Mathematics, Astronomy, Physics and Computing of the National University of Córdoba, Argentina. The opinions mentioned in this article are of the authors but not necessarily of their employer organisations. 
ASHLEY P.M., COOK N.D.J., HILL R.L., KENT A.J.R. 1994. Shoshonitic lamprophyre dykes and their relation to mesothermal $\mathrm{Au}-\mathrm{Sb}$ veins at Hillgrove, New South Wales, Australia. Lithos, 32:249-272.

AYER J.A. 1995. Precambrian Geology of Northern Swayze Greenstone Belt, Ontario Geological Survey, Report 297:71p.

AYER J.A. 1998. Trace element modeling of aqueous fluid peridotite interaction in the mantle wedge of subduction zones. Contributions to Mineralogy and Petrology, 132:390-404.

AZBEJ T., SZABÓ, C., BODNAR R.J., DOBOSI G. 2006. Genesis of carbonate aggregates in lamprophyres from the northeastern Transdanubian Central Range, Hungary: Magmatic or hydrothermal origin? Mineralogy and Petrology, 88:479-497. DOI 10.1007/s00710-006-0123-y

BAKSI A. K. 2000. Search for a deep-mantle component in mafic lavas using $\mathrm{Nb}-\mathrm{Y}-\mathrm{Zr}$ plot. Canadian Journal of Earth Sciences, 38:813824.

BAJWAH Z.U., SECCOMBE P.K., OFFLER R. 1987. Trace element distribution, Co:Ni ratios and genesis of the Big Cadia iron-copper deposit, New South Wales. Australia, Mineralium Deposita, 22:292-300.

BATKI A., PÁL-MOLNÁR E., DOBOSI G., SKELTON A. (2014). Petrogenetic significance of ocellar camptonite dykes in the Ditrâu Alkaline Massif, Romania. Lithos, 200201:181-196.

BIRD P. 1979. Continental delamination and the Colorado Plateau. Journal of Geophysical Research 84, 7561-7571.

BRALIA, A., SABATINI, G. AND TROJA, F. 1979. A revaluation of the $\mathrm{Co} / \mathrm{Ni}$ ratio in pyrite as a geochemical tool in ore genesis problems. Mineralium Deposita, 14:353-374.

CHAKRABARTI R., BASU A.R., PAUL D.K. 2007. Nd-Hf-Sr-Pb isotopes and trace element geochemistry of Proterozoic lamproites from southern India: Subducted komatiite in the source. Chemical Geology, 236:291-302. https://doi.org/10.1016/j.chemgeo.2006.10.006

CHALAPATHI RAO N.V., GIBSON S.A., PYLE D.M., DICKIN A.P. 2004. Petrogenesis of Proterozoic Lamproites and kimberlites from the Cuddapah Basin and Dharwar craton, Southern India. Journal of Petrology, 45:907948. https://doi.org/10.1093/petrology/egg116

CHALAPATHI RAO N.V., WU F.Y., MITCHELL R.H., LI Q.L., LEHMANN $\quad$ B. 2013. Mesoproterozoic $\mathrm{U}-\mathrm{Pb}$ ages, trace element and $\mathrm{Sr}-\mathrm{Nd}$ isotopic composition of perovskite from kimberlites of the Eastern Dharwar Craton, southern India: Distinct mantle sources and a widespread $1.1 \mathrm{Ga}$ tectonomagmatic event. Chemical Geology, 353:48-64.
CHALAPATHI RAO N.V., GIRI R.K., SHARMA A., PANDEY A. 2019. Lamprophyres from the Indian shield: A review of their occurrence, petrology, tectonomagmatic significance and relationship with the Kimberlites and related rocks. In: Episodes- March 2020, International Union of Geological Sciences, 231-248. https://doi.org/10.18814/epiiugs/2020/020014

CONDIE K.C, 1994. Greenstones through time. In: CONDIE, K.C. (Ed.), Archean Crustal Evolution. Developments in Precambrian Geology, 11:85-120.

COOPER A.F. 1979. Petrology of Ocellar Lamprophyres from Western Otago, New Zealand. Journal of Petrology, 20(1):139-163.

CORNELISSEN A. K.; VERWOERD W. J. 1975. The Bushmanland kimberlites and related rocks. Physics and Chemistry of the Earth, 9:71-80.

CURRIE K.L.; WILLIAMS P.R. 1993. An Archean calc-alkaline lamprophyre suite, northeastern Yilgarn Block, western Australia. Lithos, 31:3350.

DIAMOND L.W.; WIEDENBECK M. 1986. K-Ar radiometric ages of the Au-quartz veins at Brusson, Val d'Ayas, NW Italy. Swiss Bulletin of Mineralogy and Petrology, 66:385-394.

DONGRE A., JACOB D. E., STERN R. A. 2015. Subduction related origin of eclogite xenoliths from the Wajrakarur kimberlite field, eastern Dharwar craton, southern India: Constraints from petrology and geochemistry. Geochimica et Cosmochimca Acta, 166:165-188. https://doi.org/10.1016/j.gca.2015.06.023

DUBE B., WILLIAMSON K., MCNICOLL V., MALO M., SKULSKI T., TWOMEY T., SANBORN-BARRIE, M. 2004. Timing of gold mineralization at Red Lake, Northwestern Ontario, Canada: New constraints from U-Pb geochronology at the Goldcorp high- grade zone, Red Lake mine, and the Madsen mine. Economic Geology, 99:1611-1641.

FAREEDUDDIN; MITCHELL, R.M. 2012. Diamonds and Their Source Rocks in India. Journal of Geological Society of India, Bangalore, $434 \mathrm{p}$.

FITTON J.G., SAUNDERS A.D., NORRY M.J., HARDARSON B.S. AND TAYLOR R.N. 1997. Thermal and chemical structure of the Iceland plume. Earth and Planetary Science Letters, 153:197-208.

FOLEY S. 1992. Vein-plus-wall-rock melting mechanisms in the lithosphere and the origin of potassic alkaline magmas. Lithos, 28:435-453.

FREY F.A., GREEN D.H., ROY S.D. 1978. Integrated models of basalt petrogenesis: A study of quartz tholeiites to olivine melilitites from south eastern Australia utilizing geochemical and experimental petrological data. Journal of Petrology, 19:463-513.

FRIEND C. R. L.; NUTMAN, A. P. 1991. SHRIMP U-Pb geochronology of the Closepet granite and peninsular Karnataka, South of India 
gneisses. Journal of Geological Society of India, 38:357-368.

FROST R.B., CHAMBERLAIN K.R., SCHUMACHER J.C., 2000. Sphene (titanite): phase relations and role as a geochronometer. Chemical Geology, 172:131-148.

FURMAN T.; GRAHAM D. 1999. Erosion of lithospheric mantle beneath the East African Rift system: Geochemical evidence from the Kivu volcanic province, Lithos, 48: 237-262. ttps://doi.org/10.1016/S0024-4937(99)00031-6

GARZA A.O., DOSTAL, J., KEPPIE J.D., PAZMORENO F.A. 2013. Mid-Tertiary (25-21 Ma) lamprophyres in NW Mexico derived from subduction-modified subcontinental lithospheric mantle in an extensional backarc environment following steepening of the Benioff zone. Tectonophysics, 590:59-71.

GIRI R.K., PANDIT D., CHAPATHI RAO N.V. 2018. Cobaltoan Pyrite in a Lamprophyre from the Sidhi Gneissic Complex, Mahakoshal Belt. Central India, Journal of Geological Society of India, 91:5-8.

GIRI R.K., PANKAJ P., PANDIT D., SAHOO S., CHAKRABARTI R., CHALAPATHI RAO N.V. 2019. Pyroxenite dykes with petrological and geochemical affinities to the Alaskan-type ultramafics at the northwestern margin of the Cuddapah basin, Dharwar craton, southern India: Tectonomagmatic implications. Journal of Earth System Science, 128-114. https://doi.org/10.1007/s12040-019-1153-2

HALLBERG J.A. 1985. Geology and mineral deposits of the Leonora- Leverton area, northeastern Yilgarn block, Western Australia. Perth, Hesperian Press, 140p.

HOFMANN A.W., JOCHUM K.P., SEUFERT M., WHITE W. M. 1986. $\mathrm{Nb}$ and $\mathrm{Pb}$ in oceanic basalts: new constraints on mantle evolution. Earth and Planetary Science Letters, 79:33-45.

JIANG, Y.; H., JIANG, S. Y., LING, H. F., NI, P. 2010. Petrogenesis and tectonic implication of Late Jurassic shoshonitic lamprophyre dikes from the Liaodong Peninsula, NE China. Mineralogy and Petrology, 100: 127-151. https://doi.org/10.1007/s00710-010-0124-8

JOHNSON M.C.; PLANK T., 2000. Dehydration and melting experiments constrain the fate of subducted sediments. Geochemistry Geophysics Geosystems, 1(1): 1007p. https://doi.org/

10.1029/1999GC000014.

HAMILTON D.L., FREESTONE I., DAWSON, J.B., DONALDSON C.H. 1979. Origin of carbonatites by liquid immiscibility. Nature, 279 52-54.

IBRAHIM M.E., EL-TOKHI M.M., SALEH G.M., HASSAN M.A., RASHED M.A. 2007. Geochemistry of lamprophyres associated with uranium mineralization, Southeastern Desert, Egypt. Chinese Journal of Geochemistry, 26(4): 356-365. DOI: 10.1007/s11631-007-0356-4
KEPEZHINSKAS P.K., ERIKSEN G.M.D., KEPEZHINSKAS N.P. 2016. Geochemistry of ultramafic to mafic rocks in the Norwegian Lapland: inferences on mantle sources and implications for diamond exploration. Earth Science Research, 5, 148-187.

KERRICH R. 1986. Fluid infiltration into fault zones: chemical, isotopic, and mechanical effects. Pure and Applied Geophysics, 124: 225268.

KERRICH R.; WYMAN D.A. 1994. The mesothermal gold-lamprophyre association: significance for an accretionary geodynamic setting, supercontinent cycles, and metallogenic processes. Mineralogy and Petrology, 51:147172.

KOUHESTANI H., GHADERI M., LARGE R.R., ZAW K. 2017. Texture and chemistry of pyrite at Chah Zard epithermal gold-silver deposit, Iran. Ore Geology Reviews, 84:80-101.

MCNAUGHTON N., MUELLER A., GROVES D. 2005. The age of the giant Golden Mile Deposit, Kalgoorlie, Western Australia: ion-microprobe zircon and monazite $\mathrm{U}-\mathrm{Pb}$ geochronology of a syn-mineralization lamprophyre dyke. Economic Geology, 100 (7):1427-1440.

KENWORTHY S.; HAGEMANN S.G. 2005. Decoupled lamprophyric magmatism and gold mineralization at the Archean Darlot lode gold deposit, Western Australia. In: J. Mao and F.P. Bierlein (Eds.) Mineral Deposit Research: meeting the Global Challenge, 8 Biennial SGA Meeting, Beijing, China, 987-990.

KHAN S., DONGRE A., VIJOLEN F., LI, QIU-LI AND LE ROUX P. 2018. Petrogenesis of lamprophyres synchronous to kimberlites from the Wajrakarur kimberlite field: Implications for contrasting lithospheric mantle sources and geodynamic evolution of the eastern Dharwara Craton of southern India, Geological Journal, 123.DOI: $10.1002 /$ gj.3394

KORNPROBST J. 1984. Proc. 3rd International Kimberlite Conference, Kornprobst J. (ed.), Kimberlites I: Kimberlites and related rocks, Kimberlites II: The mantle and crust mantle relationships, Developments in petrology 11A and 11B, (Elsevier. 1984), New York.

KWELWA S.D. 2017. Geological controls on gold mineralization in the Kukuluma Terrain, Geita Greenstone Belt, NW Tanzania. Ph.D. Thesis, James Cook University, Australia. 206p. https://researchonline.jcu.edu.au/49987/1/49987 -kwelwa-2017-thesis.pdf

LEAKE B.E., WOOLEY A.R., ARPS C.E.S., BIRCH W.D., GILBERT M.C. 1997. Nomenclature of amphiboles: report of the subcommittee on amphiboles of the international mineralogical association, commission on new minerals and mineral names. The Canadian Mineralogist, 35:219-246.

LEELANANDAM C.; RATNAKAR J. 1980. Ocellar lamprophyres from the Purimetla 
alkaline pluton, Prakasam district, Andhra Pradesh. QuarterlyJournal of Geology, Mining and Metallurgical Society of India, 52(2):77-79.

LEFEBVRE N., KOPYLOVA M., KIVI K. 2005. Archean calc-alkaline lamprophyres of Wawa, Ontario, Canada: Unconventional diamondiferous volcaniclastic rocks. Precambrian Research, 138:57-87.

LE MAITRE, R.W. (Ed.), 2002. Igneous Rocks: A Classification and Glossary of Terms. Recommendations of the International Union of Geological Sciences Subcommission on the Systematics of Igneous Rocks. Cambridge University Press, Cambridge, 236p.

MADHAVAN V., DAVID K., MALLIKHARJUNA RAO J., CHALAPATHI RAO N.V., SRINIVAS M. 1998. Comparative study of lamprophyres from the Cuddapah Intrusive Province (CIP) of Andhra Pradesh, India. Journal Geological Society of India 52:624-642.

MANIKYAMBA C., KERRICH R., NAQVI S.M., RAM MOHAN M. 2004. Geochemical systematics tholeiitic basalts from the $2.7 \mathrm{Ga}$ Ramagiri-Hungund composite greenstone belt, Dharwar Craton. Precambrian Research, 134:21-39.

MATHIEU L., BOUCHARD E., GUAY F., LIENARD A., PILOTE P., GOUTIER J. 2018. Criteria for the recognition of Archean calcalkaline lamprophyres: examples from the Abitibi Subprovince. Canadian Journal of Earth Sciences, $\quad 55 \quad$ (2):188-205. https://doi.org/10.1139/cjes-2017-0152

MESHRAM R.; VENKATESWARA RAO S. 2009. Mineralogy and geochemistry of lamprophyres from Kalwakurty, Mahbubnagar district, Andhra Pradesh, Indian Journal of Geosciences, 63(4): 361-372.

MESHRAM T.M., SHUKLA D, BEHERA K.K. 2015. Alkaline lamprophyre (camptonite) from area, NE margin of the Eastern Dharwar Craton, southern India. Current Science, 109(11):19311934.

MHLANGA G. 2002. Data driven predictive modelling for Archean lode gold potential, Bubi greenstone belt, southwest Zimbabwe, M.Sc. dissertation, International institute for GeoInformaiton and Earth observation, The Netherlands, 126p.

MITCHELL R. H. 2005. Carbonatites and carbonatites and carbonatites, Canadian Mineralogist, 43: 2049-2068.

MOYEN J-F., NEDELE, A., MARTIN H., JAYANANDA M. 2003. Syntectonic granite emplacement at different structural levels: the Closepet granite, South India. Journal of Structural Geology, 25:611-631.

MÜlLER D.; GROVES D.I. 2019. Potassic igneous rocks and gold-copper mineralization, fifth edition. Mineral resource reviews, Springer, 398p.
MUELLE A.G., HARRIS L.B., LUNGAN A. 1988. Structural control of greenstone-hosted gold mineralization by transcurrent shearing: A new interpretation of the Kalgoorlie mining district. Ore Geology Reviews, 3:359-387.

NASIR S. 2016. Petrology of Late Jurassic allochthonous Ultramafic Lamprophyre within the Batain Nappes, Northeastern Oman. International Geology Review, 58(8):913-928.

NAQVI S.M., KHAN R.M.K., MANIKYAMBA C., RAM MOHAN M., KHANNA T.C., 2006. Geochemistry of Neoarchean High-Mg basalts, boninites and adakites from the KushtagiHungund greenstone belt of the Eastern Dharwar Craton (EDC); implications for the tectonic setting. Journal of Asian Earth Sciences, 27:25-44.

NAYAK S.S.; KUDARI S.A.D. 1999. Discovery of diamond bearing kimberlites in Kalyandurg area, Anantapur District, Andhra Pradesh. Current Science, 76 (8):1077-1079.

NÖRTEMANN F.-J., M., MÜCKE A., WEBER K. MEINERT D. 2000. Mineralogy of the Navachab skarn deposit, Namibia: an unusual Au-bearing skarn in high-grade metamorphic rocks. Communications of Geological Survey of Namibia, 12:169-177.

NUTMAN A.P., CHADWICK B., KRISHNA RAO B., VASUDEV V. N. 1996. SHRIMP U/Pb ages of acid volcanic rocks in the Chitradurga and Sandur groups and granites adjacent to the Sandur schist belt, Karnataka. Journal of Geological Society of India, 47:153-164.

PANDEY A., CHALAPATHI RAO N.V., CHAKRABARTI R., PANKAJ P., PANDIT D., PANDEY R., SAHOO S. 2018. Post-collisional calc-alkaline lamprophyres from the Kadiri greenstone belt: Evidence for the Neoarchean convergence-related evolution of the Eastern Dharwar Craton and its schist belts. Lithos, 320321:105-117.

PANDEY A., CHALAPATHI RAO N.V., PANDIT D., PANKAJ, P., PANDEY R., SAHOO S., KUMAR A. 2017. Subduction-tectonics in the evolution of the eastern Dharwar craton, southern India: Insights from the postcollisional calc-alkaline lamprophyres at the western margin of the Cuddapah basin. Precambrian Research, 298: 235-251.

PANDEY A., CHALAPATHI RAO N.V., CHAKRABARTI R., PANDIT D., PANKAJ P., KUMAR A., SAHOO S. 2017. Petrogenesis of a Mesoproterozoic shoshonitic lamprophyre dyke from the Wajrakarur kimberlite field, Eastern Dharwar Craton, southern India: Geochemical and $\mathrm{Sr}-\mathrm{Nd}$ isotopic evidence for a modified sub-continental lithospheric mantle source. Lithos, 292-293:218-233.

PANDEY A., PANDEY R., PANDIT D., PANKA, P., CHALAPATHI RAO N.V. 2016. Origin of clinopyroxene megacrysts from the Udiripikonda lamprophyre, Eastern Dharwar 
Craton, southern India. In:33rd Convention of Indian Association of Sedimentologists, Department of Geology, Centre for Advanced Study, Banaras Hindu University, Varanasi, $157 \mathrm{p}$.

PANKAJ P., GIRI R.K., CHALAPATHI RAO N.V., CHAKRABARTI R. AND RAGHUVAMSHI S. 2020. Mineralogy and Petrology of shoshonitic lamprophyre dykes from the Sivarampeta area, diamondiferous Wajrakarur Kimberlite Field, Eastern Dharwar craton, Southern India, Journal of Mineralogical and Petrological Sciences, J-STAGE Advance Publication, 1-14.

PATEL S.C., RAVI S., ANILKUMAR Y., NAIK A., THAKU, S.S., PATI J.K., NAYAK S.S. 2009. Mafic xenoliths in Proterozoic kimberlites from Eastern Dharwar Craton, India: Mineralogy and P-T regime. Journal of Asian Earth Sciences, 34:336-346. https://doi.org/10.1016/j. jseaes.2008.06.001

PECCERILLO A.,; TAYLOR S. R. 1976. Geochemistry of Eocene calc-alkaline volcanic rocks of the Kastamonu area, northern Turkey. Contributions to Mineralogy Petrology, 58:6381. https://doi.org/10.1007/ BF00384745

PERRING C.S., ROCK N.M.S., GOLDING S.D., ROBERTS D.E. 1989. Criteria for the recognition of metamorphosed or altered lamprophyres: a case study from the Archean of Kambalda, western Australia. Precambrian Research, 43: 215-237.

PHANI P.R.C., RAJU V.V.N., SRINIVAS M. 2018. Petrological and Geochemical Characteristics of a Shoshonitic Lamprophyre, Sivarampet, Wajrakarur Kimberlite Field, Southern India. IOSR Journal of Applied Geology and Geophysics, 6(2):55-69.

PHILLPOTTS A.R. 1990. Principles of Igneous and Metamorphic Petrology. Prentice Hall, Englewood Cliffs, New Jersey, 498p.

POLAT A.; KERRICH R. 2001. Magnesian andesites, Nb-enriched basalt-andesites, and adakites from late Archean $2.7 \mathrm{Ga}$ Wawa greenstone belts, Superior Province, Canada: implications for late Archean subduction zone petrogenetic processes. Contributions to Mineralogy and Petrology, 141:36-52.

RAGHUVAMSHI S., PANDEY A., PANKAJ P., CHALAPATHI RAO N.V., CHAKRABARTI R., PANDIT D., PANDEY R. 2019. Lithosphere-asthenosphere interaction and carbonatite metasomatism in the genesis of Mesoproterozoic shoshonitic lamprophyres at Korakkodu, Wajrakarur kimberlite field, Eastern Dharwar Craton, southern India, Geological Journal, Special Issue Article, 1-18.

RAMAKRISHNAN M. AND VAIDYANADHAN R. 2008. Geology of India. Geological Society of India, 1: 556p.

RAMAMURTHY S.; ANANDAMURTHY S. 1994. Report on preliminary investigation for
Gold in Kadiri schist belt, Anantapur district, Andhra Pradesh, Progress report, Geological Survey of India, 43p.

RATHNA K., VIJAYAKUMAR K., RATNAKAR J. 2000. Petrology of the Dykes at Ravipadu, Prakasam Province, Andhra Pradesh, India. Journal of Geological Society of India, 55(4): 399-412.

RATNAKAR J., VIJAYAKUMAR K., RAMAKRISHNA D.V. AND NAGASAI SARMA V. 1995. An alkaline lamprophyre (camptonite) from Ravipadu, Prakasam province, Andhra Pradesh, India. Current Science, 68: 956-959.

RATNAKAR J., RAMAKRISHNA D. V., VIJAYAKUMAR K. 1996. Geochemistry and origin of Kellampalle lamprophyre, Prakasam province, Andhra Pradesh. Journal of Geological Society of India, 48:697-702.

RAVI S., VAIDESWARAN T., BHASKARA RAO K.S. 2009. Field Guide to Wajrakarur Kimberlite Field, Anantapur district, Andhra Pradesh, Field Workshop, Wajrakarur Kimberlite Field, Geological Survey of India, 26-31: 54p.

ROCK N.M.S.,; GROVES D.I. 1988. Do lamprophyres carry gold as well as diamonds? Nature, 332:235-255. doi:10.1038/332253a0.

ROCK N.M.S, DULLER P., HASZELDINE R.S., GROVES, D.I. 1987. Lamprophyres as potential gold exploration targets: Some preliminary observations and speculations University Western Australia Geology Department, Univ. Ext. Pub., 11:271-286.

ROCK N.M.S., GROVES D.I., Perring C.S. 1988. Gold, lamprophyres and porphyries: A new genetic model: Geological Society of Australia Abstracts, 22:3-22.

ROCK N.M.S. 1987. The nature and origin of lamprophyres: an overview. Geological Society of London, Special Publication 30: 191-226.

ROCK N.M.S. 1991. Lamprophyres. Blackie, London 225p.

RUDNICK R. L.; GAO S. 2003. Composition of the continental crust; Treatise on Geochemistry 3: $659 \mathrm{p}$.

SANISLAV I., KOLLING S.L., BRAYSHAW M., YVONNE A.C., PAUL H.GM., THOMAS G.B., MARWA I.M., ROGER R. 2015. The geology of the giant Nyakanga gold deposit. Ore Geology Reviews, 69:1-16.

SCARROW J.H., MOLINA J.F., BEA F., MONTERO P., VAUGHAN A.P.M. 2011. Lamprophyre dikes as tectonic markers of late orogenic transtension timing and kinematics: A case study from the Central Iberian Zone, Tectonics, TC4007, 30(4):22p.

SHAIKH A.M., PATEL S.C. RAVI S. D. BEHERA D., PRUSETH K.L. 2016. Mineralogy of the TK1 and TK4 'kimberlites' in the Thimmasamudram cluster, Wajrakarur Kimberlite Field, India: Implications for 
lamproite magmatism in a field of kimberlites and ultramafic lamprophyres. Chemical Geology, http://dx.doi.org/10.1016/j.chemgeo.2016.10.03 0

SHIVANNA S., SRIVASTAVA J. K., NAMBIAR A. R. 2002. Kimberlite occurrence in Raichur area, Karnataka, comments by V. Madhavan. Journal Geological Society of India, 60, 478480.

SIDDORN J.P. 2011. The Giant-Con Gold Deposit: A once-linked Archean Lode-Gold System. Ph.D. Thesis, University of Toronto. 330p.

SILLITOE R.H.,; THOMPSON J.F.H. 1998. Intrusion-related vein gold deposits: types, tectono-magmatic settings and difficulties of distinction from orogenic gold deposits. Resource Geology, 48(2):237-250.

SIMS P.K.; DAY W.C. 1992. A Regional Structural Model for Gold Mineralization in the Southern Part of the Archean Superior Province, United States. Chapter M, In: Contributions to Precambrian Geology of Lake Superior Region. U.S. Geological Survey Bulletin, 1904, 28p. https://pubs.usgs.gov/bul/1904m/report.pdf

SINCLAIR W. D. 2007. Porphyry deposits. In W. D. Goodfellow, (Ed.), Mineral Deposits of Canada. A synthesis of Major Deposit Types. Geological Association of Canada, Mineral Deposits Division, Ottawa, Special Publication No.5:223-243.

SMITH E.I., SÁNCHE A., WALKER J.D., WANG K. 1999. Geochemistry of mafic magmas in the hurricane volcanic field, Utah: implications for small- and large-scale chemical variability of the lithospheric mantle. Journal of Geology, 107:433-448.

SRIVASTAVA R.K. 2008. Global intracratonic boninite-norite magmatism during the Neoarchean-Paleoproterozoic: evidence from the central Indian Bastar craton. International Geology Reviews 50:61-74.

SRIVASTAVA R.K. 2013. Petrological and geochemical characteristics of Paleoproterozoic ultramafic lamprophyres and carbonatites from the Chitrangi region, Mahakoshal supracrustal belt, central India. Journal of Earth System Science 122(3):759-776.

SRIVASTAVA R. K.; CHALAPATHI RAO N.V. 2007. Petrology, geochemistry and tectonic significance of Palaeoproterozoic alkaline lamprophyres from the Jungel Valley, Mahakoshal supracrustal belt, Central India. Mineralogy and Petrology, 89: 189-215.

SRIVASTAVA R.K., SINGH R.K., VERMA S.P. 2004. Neoarchean mafic volcanic rocks from the southern Bastar greenstone belt, Central India: petrological and tectonic significance. Precambrian Research, 131:305-322.

ŠTEMPROK M.; SEIFERT T. 2011. An overview of the association between lamprophyric intrusions and rare-metal mineralization, Mineralogia, 42(2-3):121-162.

STERN R.J. 2002. Subduction zones. Reviews in Geophysics, 40:1012. http://dx.doi.org/ 10.1029/2001RG000108.

STOPPA F., RUKHLOV A.S., BELL K., SCHIAZZA M., VICHI G. 2014. Lamprophyres of Italy: early Cretaceous alkaline lamprophyres of Southern Tuscany, Italy. Lithos, 188; 97-112.

SUBRAHMANYAM K., MALLIKARJUNA RAO J., LEELANANDAM C. 1987. Occurrence of lamprophyre dykes near Khammam, Andhra Pradesh, Indian Journal of Geology, 35:65-70.

SUGAVANAM E.B., MALLIKARJUNA C., VIDYADHARAN K.T. 1994. Archaean Meta Lamprophyres from Nuggihalli Schist Belt, Hassan District, Karnataka. Geological Society of India, 43(2):115-137.

SUN S.; MCDONOUGH W. F. 1989. Chemical and isotopic systematics of oceanic basalt: Implications for mantle composition and processes. In A. D. Saunders; M. J. Norry (Eds.), Magmatism in the ocean basins, London: Geological Society of London Special Publication, 42:313-345.

SWAMI NATH J., RAMAKRISHNAN M., VISWANATHA M.N. 1976. Dharwar stratigraphic model and Karnataka cratonic evolution. Records of Geological Survey of India, 107:149-175.

TAPPE S., FOLEY S. F., JENNER G.A, HAMAN L.M., KJARSGAARD B.A., ROMER R. L., STRACKE A., JOYCE N. HOEFS J. 2006. Genesis of ultramafic lamprophyres and carbonatites at Aillik Bay, Labrador: A consequence of incipient lithospheric thinning beneath the North Atlantic craton, Journal of Petrology, 47:1261-1315.

TAYLOR W.R., ROCK N.M.S., GROVES D.I., PERRING C.S., GOLDING S.D. 1994. Geochemistry of Archean lamprophyres from the Yilgarn Block, Western Australia: Au abundance and association with gold mineralization, Applied Geochemistry, 9:197222.

VASUDEV V.N. 2009. Field Guide to selected Gold Prospects in Karnataka and Andhra Pradesh. Geological Society of India, May30June 05 .

VICHI G., STOPPA F., WALL F. 2005. The carbonate fraction in carbonatitic Italian lamprophyres. Lithos, 85:154-170.

VIJAYA KUMAR K.; RATNA K. 2008. Geochemistry of the mafic dykes in the Prakasam Alkaline Province of Eastern Ghats Belt, India: Implications for the genesis of continental rift zone magmatism. Lithos, 104:306-326. https://doi.org/10.1016/j.lithos.2007.12.012

WILLIAMS H. 1994. The lithological setting and controls on gold mineralization in the Southern Ore Zone of the Hampton-Boulder gold deposit, 
New Celebration Gold Mine, Western Australia. Unpublished BSc (Hons) thesis, University of Western Australia.

WITT W.K.; HAMMOND D.P. 2008. Archaean gold mineralization in an intrusion related, geochemically zoned district-scale alteration system in the Carouse Basin, Western Australia. Economic Geology, 103:445-454.

WYMAN D.; KERRICH R. 1988. Alkaline magmatism, major structures, and gold deposits Implications for greenstone belt gold metallogeny. Economic Geology, 83:454-461.
ZACHARIAH J.K., MOHANTA M.K. AND RAJAMANI V. 1996. Accretionary evolution of the Ramagiri schist belt, Eastern Dharwar Craton. Journal of Geological Society of India, 47:279-291.

ZHILONG H., CHONGQIANG L., HAILING Y., CHENG XU, RUNSHENG H., YUNHUA X., BO Z., WENBO LI. 2002. The geochemistry of lamprophyres in the Laowangzhai gold deposits, Yunnan Province, China: Implications for its characteristic of source region. Geochemical Journal, 36:91-112. 